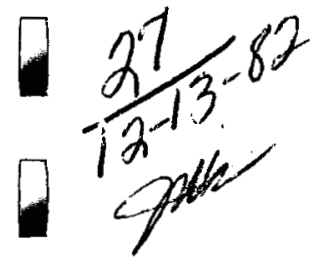

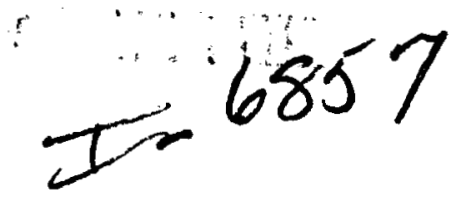

\section{Radiological Health Aspects of Commercial Uranium Conversion, Enrichment, and Fuel Fabrication}

\author{
G. A. Stoetzel \\ G. R. Hoenes \\ F. M. Cummings \\ W. D. McCormack
}

DO NOT MOTOTLM 2. COVEH

November $1982 \checkmark$

Prepared by

Pacific Northwest Laboratory for Hanford

Environmental Health Foundation and the

U.S. Department of Energy under Contract

DE-AC06-76RLO 1830 


\section{DISCLAIMER}

This report was prepared as an account of work sponsored by an agency of the United States Government. Neither the United States Government nor any agency Thereof, nor any of their employees, makes any warranty, express or implied, or assumes any legal liability or responsibility for the accuracy, completeness, or usefulness of any information, apparatus, product, or process disclosed, or represents that its use would not infringe privately owned rights. Reference herein to any specific commercial product, process, or service by trade name, trademark, manufacturer, or otherwise does not necessarily constitute or imply its endorsement, recommendation, or favoring by the United States Government or any agency thereof. The views and opinions of authors expressed herein do not necessarily state or reflect those of the United States Government or any agency thereof. 


\section{DISCLAIMER}

Portions of this document may be illegible in electronic image products. Images are produced from the best available original document. 


\title{
DISCLAIMER
}

This report was prepared as an account of work sponsored by an agency of the United States Government. Neither the United States Government nor any agency thereof, nor any of their employees, makes any warranty, express or implied, or assumes any legal liability or responsibility for the accuracy, completeness, or usefulness of any information, apparatus, product, or process disclosed, or represents that its use would not infringe privately owned rights. Reference herein to any specific commercial product, process, or service by trade name, trademark, manufacturer, or otherwise, does not necessarily constitute or imply its endorsement, recommendation, or favoring by the United States Government or any agency thereof. The views and opinions of authors expressed herein do not necessarily state cr reflect those of the United States Government or any agency thereof.

\author{
PACIFIC NORTHWEST IABORATORY \\ operated by \\ BATTELLE \\ for the \\ UNITED STATES DEPARTMENT OF ENERGY \\ under Contract DE-AC06-76RLO 1830
}

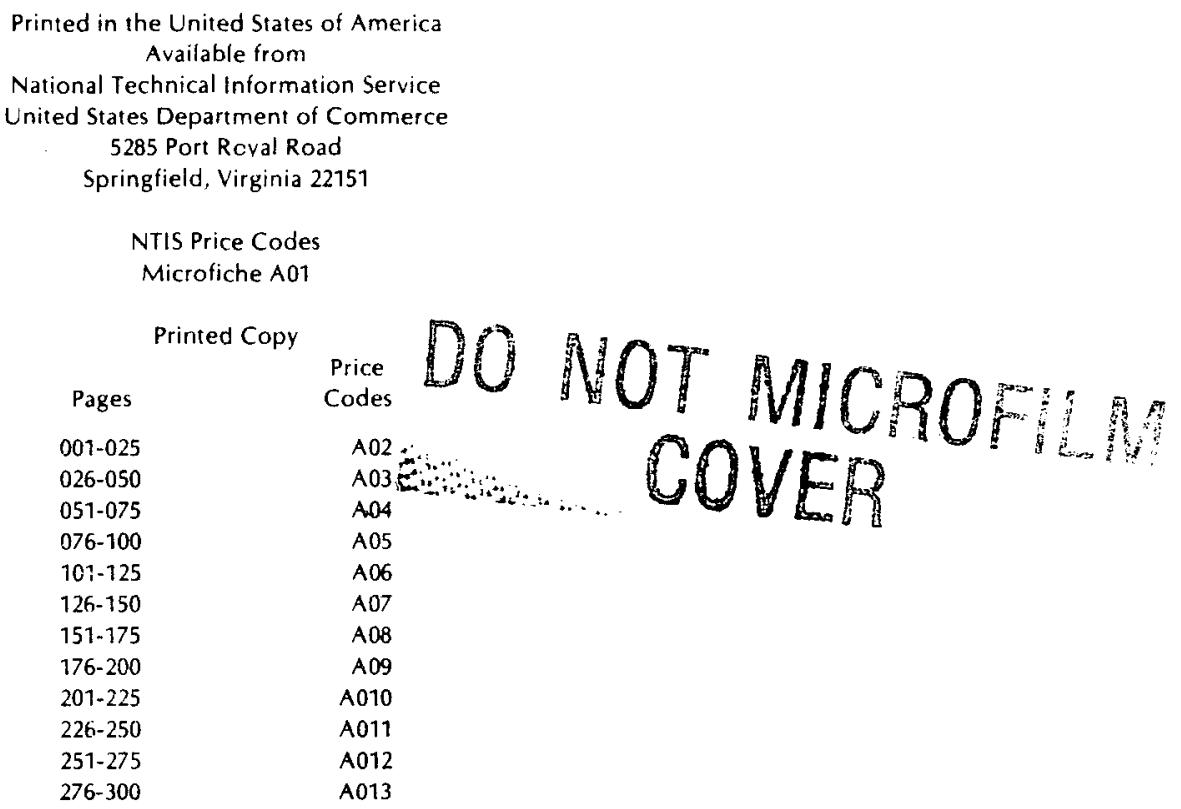




\title{
Radiological Health Aspects of Commercial Uranium Conversion, Enrichment, and Fuel Fabrication
}

\author{
G. A. Stoetzel \\ G. R. Hoenes \\ F. M. Cummings \\ W. D. McCormack
}
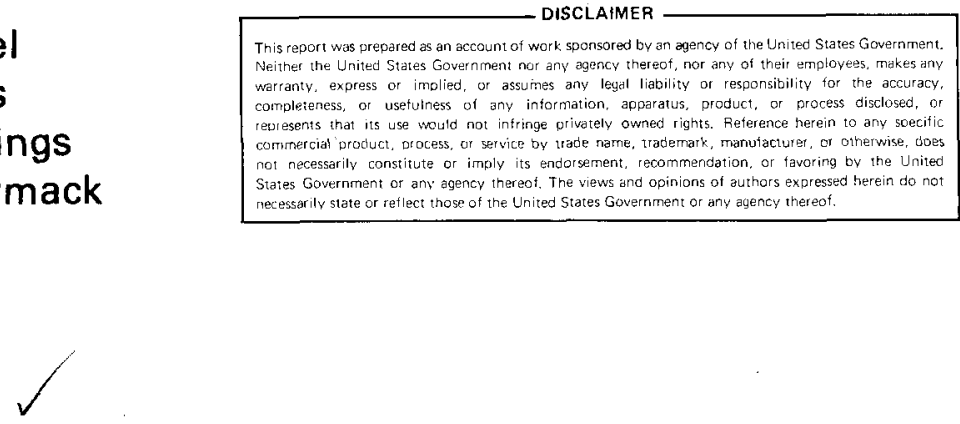

Prepared by Pacific Northwest Laboratory for Hanford Environmental Health Foundation and the U.S.

Department of Energy under Contract DE-ACO6-76RLO 1830 
.



D

.

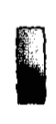

$B$

5

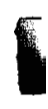

8

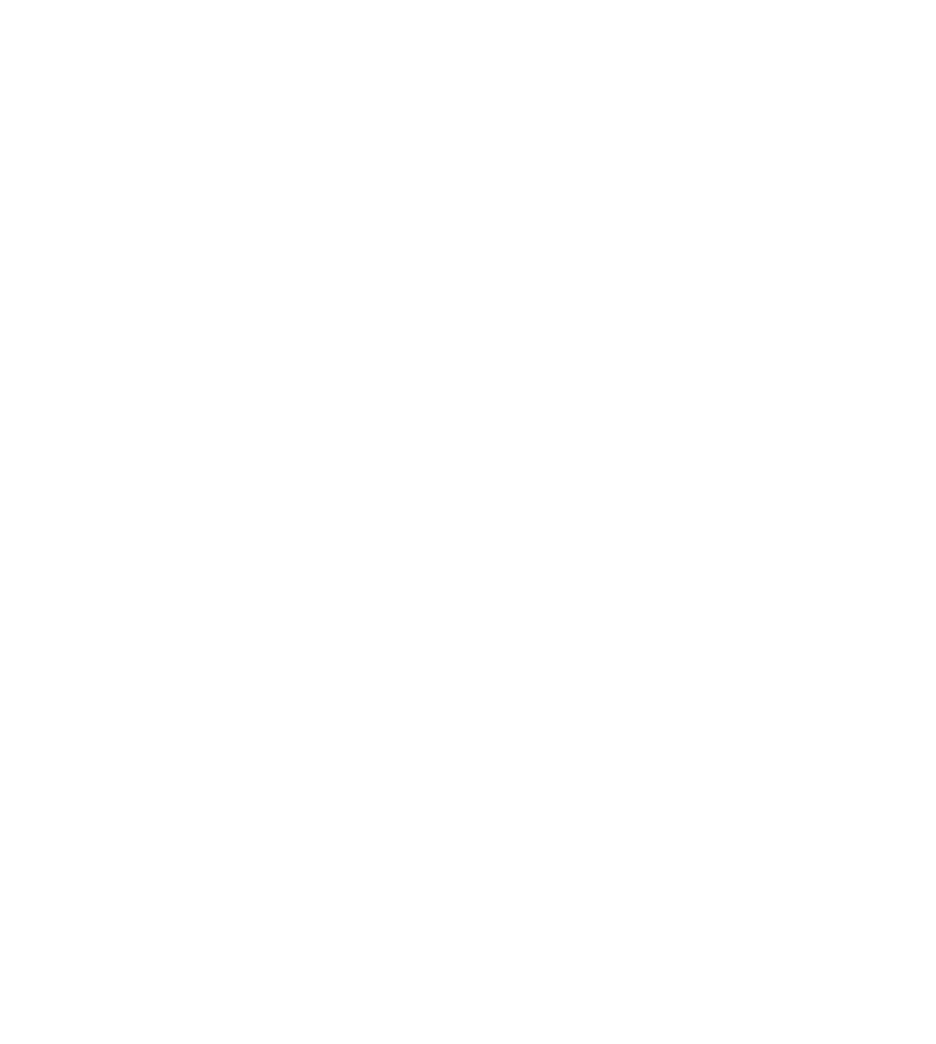

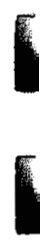

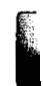


PREFACE

1.0 INTRODUCTION

1.1 SCOPE

1.2 SUMMARY

1.2.1 Radiological Health Physics. . . . . . 3

1.2.2 Radiological Exposure . . . . . . . . 3

1.2.3 Nonradiological Exposures . . . . . . . 44

1.2.4 Regulatory Aspects . . . . . . . . . 5

2.0 GENERAL RADIOLOGICAL HEALTH PRACTICES . . . . . . . 6

2.1 FACILITY MONITORING . • • • • • • • • . 6

2.1.1 Airborne Particulate Sampling . . . . . 7

2.1.2 Surveys for the Control of Surface Contamination . 7

2.1.3 External Gamma Radiation Surveillance . . . . 8

2.2 EXPOSURE CONTROL

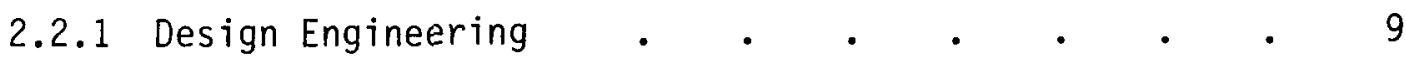

2.2.2 Respiratory Protection . . . . . . . . 9

2.2.3 Contamination Control . . . . . . . .

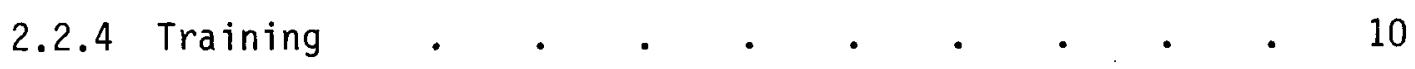

2.3 EXPOSURE EVALUATION •

2.3.1 Bioassay Programs . . . . . . . . . . . 13

2.3.2 External Exposures . . . . . • • 17

2.3 .3 Record Keeping . . . . . . . . . . . 17

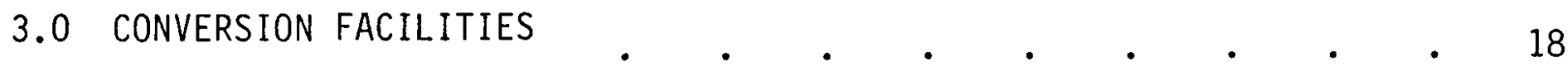

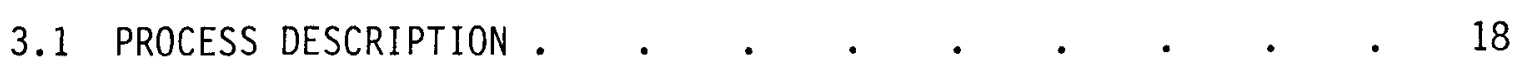




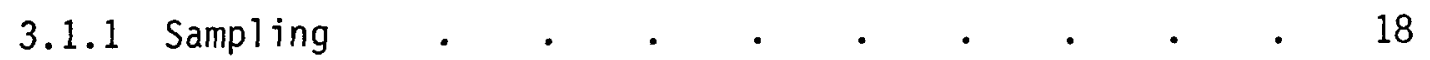

3.1 .2 Feed Preparation . . . . . . . . . 20

3.1.3 Conversion and Purification . . . . . . . 21

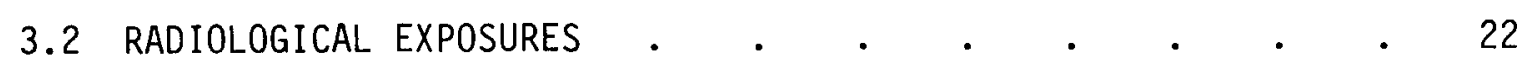

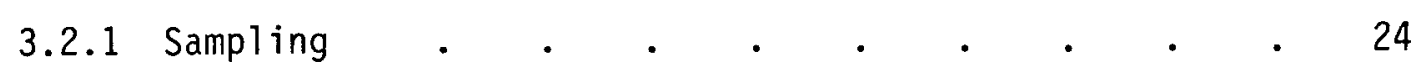

3.2.2 Feed Preparation . . . . . . . . . 25

3.2.3 Conversion and Purification . . . . . . 25

3.2.4 UF 6 Cylinder Handling . . . . . . . . . 26

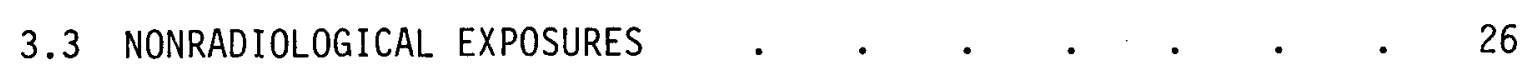

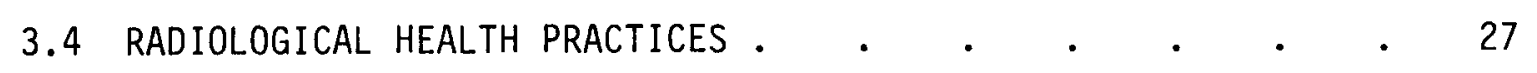

3.4.1 Facility Monitoring . • . • • • • 27

3.4 .2 Exposure Control . . . . . . . . . 28

3.4.3 Exposure Evaluation . . . . . . . . 29

3.5 REGULATORY PROCEDURE . . . . . . . . . . 30

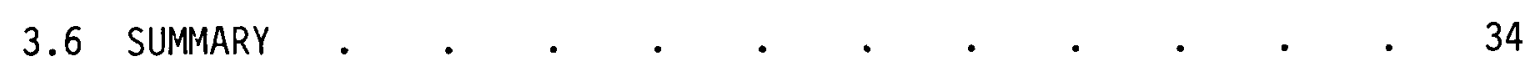

4.0 ENRICHMENT FACILITIES $. \quad . \quad . \quad . \quad$. . . . . . . . . 35

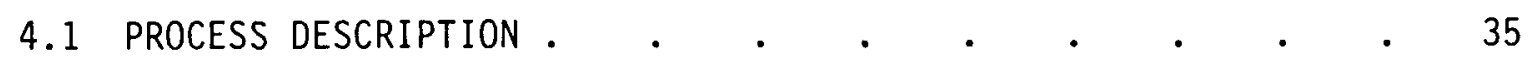

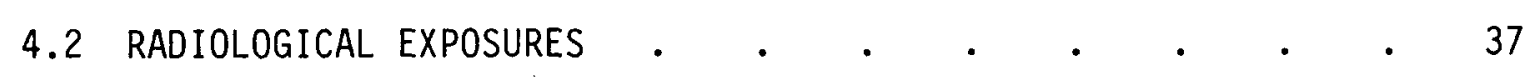

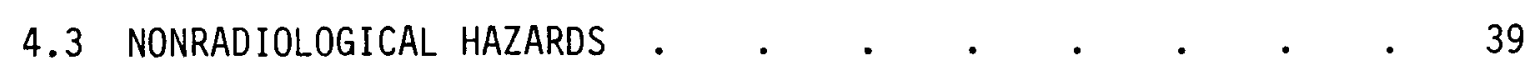

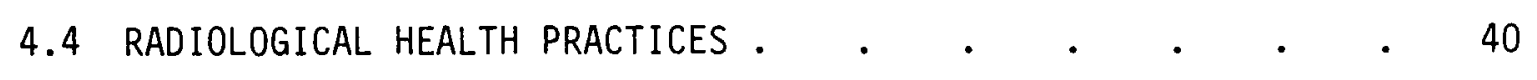

4.4.1 Facility Monitoring . . . . . . . . 40

4.4 .2 Exposure Control . . . . . . . . . 41

4.4.3 Exposure Evaluation . . . . . . . . 41

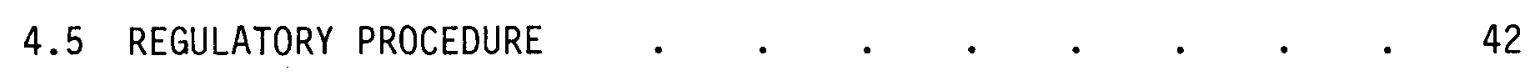

4.6 SUMMARY . . . . . . . . . . . . . . . . . 44 


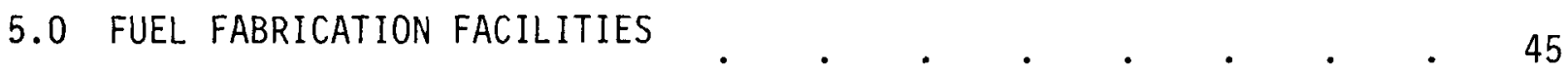

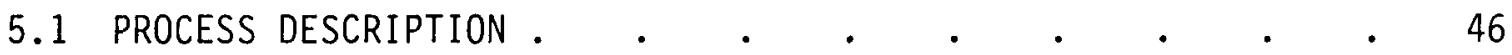

5.1 .1 Powder Production . . . . . . . . . . 47

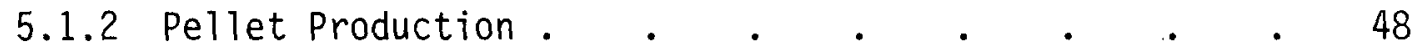

5.1 .3 Fuel Assembly . . . . . . . . . . . 49

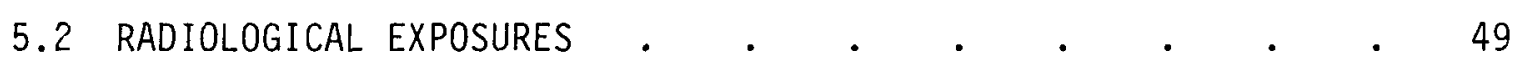

5.2 .1 Powder Production . . . . . . . . . 50

5.2 .2 Pellet Production . . . . . . . . 51

5.2 .3 Fuel Assembly $\quad$. $\quad . \quad$. . . . . . . 52

5.3 NONRADIOLOGICAL HAZARDS . . . . . . . . . . 52

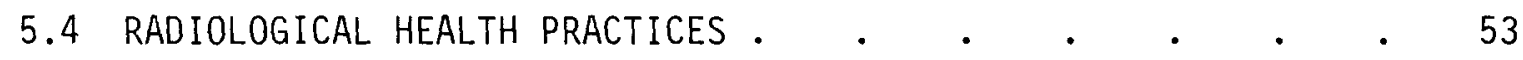

5.4 .1 Facility Monitoring . . . . . . . . 53

5.4 .2 Exposure Control . $\quad$. $\quad . \quad$. $\quad . \quad$. 54

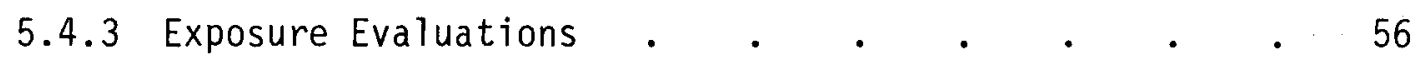

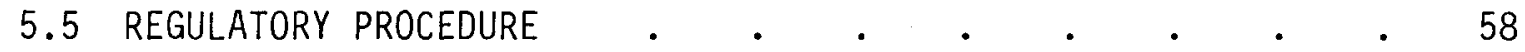

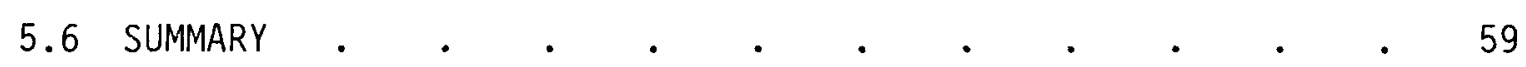

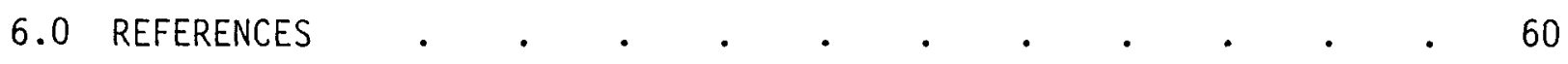




\section{FIGURES}

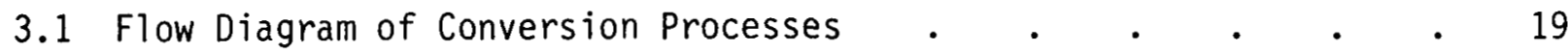

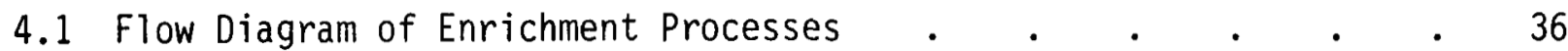

5.1 Flow Diagram of Fuel Fabrication Process _ . . . . . . . 46

\section{TABLES}

2.1 Solubility Classification of Selected Uranium Compounds $\quad$ • $\quad$ - 12

2.2 Corrective Actions Based on Urinary Uranium Concentration

Results . . . . . . . . . . . . . . . 15

2.3 Corrective Actions Based on In-Vivo Results . . . . . . . 16

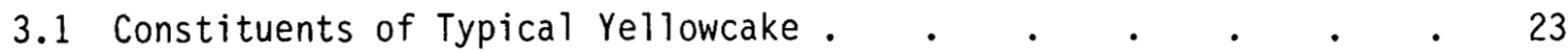

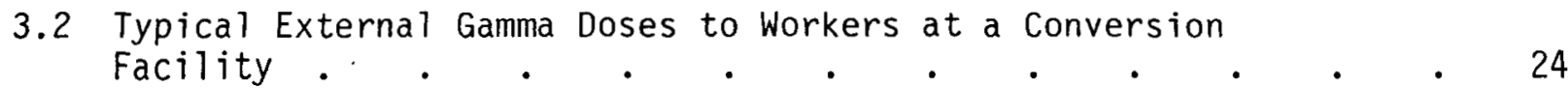

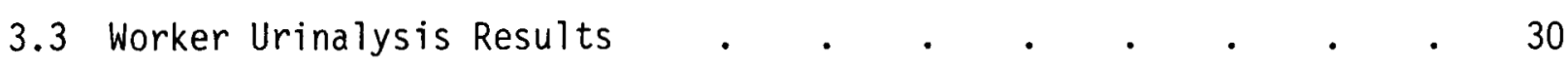

3.4 Total Occupational Dose Limited Per Quarter from 10 CFR 20 . . 31

3.5 Maximum Permissible Airborne Concentrations of

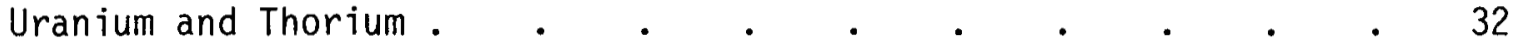

3.6 Required Records and Retention Periods . . . . . . . . . 33

4.1 Radiation Protection Standards for External and Internal

5.1 Currently Operating Fuel Fabrication Facilities . • • • • 45 


\section{PREFACE}

This report is the third in a series of reports written as part of the United States Uranium Registry Program. The first report, (PNL-3341 USUR-01) entitled "Occupational Exposures to Uranium: Processes, Hazards and Regulations - A Field Study of the Commercial Fuel Cycle," was published in April 1981. The second report (USUR-02), entitled "An Appraisal of Selected Epidemiologic Issues From Studies of Lung Cancer Among Uranium and Hard Rock Miners," was published in April 1982. 
RADIOLOGICAL HEALTH ASPECTS OF COMMERCIAL URANIUM

CONVERSION, ENRICHMENT, AND FUEL FABRICATION

\subsection{INTRODUCTION}

The United States Uranium Registry (USUR) was formed in 1978 to investigate potential hazards from occupational exposure to uranium and to assess the need for special health-related studies of uranium workers. The need for information on the behavior and effects of uranium in man was emphasized at the U.S. Energy Research and Development Administration's conference on occupational health experience with uranium in 1975. In response to this need, the U.S. Department of Energy provided funding to the Hanford Environmental Health Foundation to establish the USUR. Pacific Northwest Laboratory was identified to provide technical support in the area of health physics.

The major goals of the Registry are to:

- characterize the processes and the occupational health aspects of the uranium fuel cycle

- determine the concentration and distribution of uranium and its decay daughters in the tissues of exposed workers

- identify populations suitable for special health-related studies.

Personnel working for the USUR have visited 35 uranium facilities to collect information toward accomplishment of these goals. Facilities visited include currently operating commercial uranium facilities (mines, mills, conversion plants, enrichment plants, and fuel fabrication plants) and several noncommercial and inactive uranium facilities. Information obtained to date covers general facility descriptions, process descriptions, radiological exposures, regulatory requirements, radiological health practices, nonradiological exposures, and occupational medicine programs. The information-gathering phase of the program reinforced the original sense that a post-mortem tissue program 
for uranium workers is needed. The current lack of information on the deposition, distribution, and retention of various uranium compounds in man greatly increases the difficulty of developing appropriate standards for uranium exposure and, consequently, worker protection policies. The tissue program will in due course provide that information.

\subsection{SCOPE}

A summary of the Registry's activities is provided in a recent report by the USUR (Stoetzel et al. 1981). This report provides more detailed information concerning occupational exposures, health physics practices, and regulatory procedures at commercial conversion, enrichment and fuel fabrication facilities. Sites visits were the primary source of information for the report.

This report is divided into four sections. The first section discusses health physics practices that are common to the conversion, enrichment, and fuel fabrication phases of the commercial uranium industry. The next three sections review process descriptions, radiological health practices, and regulatory procedures for the three phases. Nonradiological exposures are considered only as they influence the interpretation of the health effects of radiological exposures. The review of regulatory procedures indicates the types of exposure evaluation records being kept on uranium workers and the responsibility for maintaining the records. This information is valuable in the establishment of worker-health studies.

\subsection{SUMMARY}

This report focuses on the conversion, enrichment, and fuel fabrication facilities of the commercial uranium fuel production industry. The radiological health practices and potential radiation exposure of workers in these facilities are emphasized. Nonradiological hazards are identified only as factors that might influence assessment of the impact of radiological hazards. 


\subsubsection{Radiological Health Physics}

The four general methods used to identify and control radiation hazards are: facility monitoring, exposure control, exposure evaluation, and record keeping.

- Facility monitoring. Air in the breathing zone is monitored for suspended uranium nuclides, and working locations are surveyed for surface contamination or accumulation of alpha, beta, or gammaemitting materials. Monitoring locations and frequency of sampling or measurements are selected by considering the quantities of radioactive materials in the production processes, the potential for escape from a system into the workplace, and the proximity of the release to the worker.

- Exposure control. Design engineering is used to prevent and control releases of radioactive material into the workers' environment. Respiratory protection programs and protective clothing are provided. Training programs are used to help control exposures of personnel.

- Exposure evaluation. Bioassay techniques (urinalysis and chest counting) are used for estimating internal depositions of uranium. External gamma monitoring is also used to determine personnel dose. The frequency of urinalysis for uranium varies among the facilities. Chest counting is routinely performed at conversion, enrichment, and fuel fabrication facilities.

- Record keeping. Regulatory agencies require that records of facility monitoring and exposure evaluation data be maintained by each licensed facility.

\subsubsection{Radiological Exposure}

Internal deposition of uranium through inhalation is the most important pathway of occupational exposures in this portion of the uranium industry. External radiation exposure of personnel is of secondary conern. Maximum external doses are usually less than $2 \mathrm{rem} / \mathrm{yr}$. 
Areas in conversion, enrichment, and fuel fabrication facilities where internal deposition of uranium is most likely to occur are discussed below:

- Conversion. Inhalation of yellowcake, uranium tetrafluoride $\left(U_{4}\right)$, uranium dioxide $\left(\mathrm{UO}_{2}\right)$, uranium trioxide $\left(\mathrm{UO}_{3}\right)$, and uranyl fluoride $\left(\mathrm{UO}_{2} \mathrm{~F}_{2}\right)$ may occur at different stages of the conversion process. The activities with the greatest potential for inhalation exposures are yellowcake sampling, removal of ash waste following purification, and maintenance.

- Enrichment. The primary chemical form of uranium to which workers are exposed is uranyl fluoride $\left(\mathrm{UO}_{2} \mathrm{~F}_{2}\right)$ formed when uranium hexafluoride $\left(U_{6}\right)$ reacts with moisture in the air. Inadvertant release of $U_{6}$ may occur during sampling, UF 6 cylinder loading and unloading, and maintenance activities.

- Fuel Fabrication. Workers may be exposed to ammonium diuranate $(A D U), U_{2} F_{2}$, and $U_{2}$ powder. The primary inhalation hazard is to uranium dioxide powder during packaging and unpackaging, powder handling and pellet production, and maintenance activities.

Uranium can present both a radiological and chemical hazard to workers. The chemistry of a uranium compound determines its solubility in body fluids and its retention. time in the tissues. Both soluble and insoluble forms of uranium may accumulate in different parts of the body through chronic exposure and remain there for long periods, resulting in a radiological hazard. Soluble forms also represent a chemical hazard to kidney tissue. The solubility of inhaled uranium compounds is only one of many factors to be considered in estimating dose from internally deposited uranium.

\subsubsection{Nonradiological Exposures}

Exposures to nonradiological hazards in the uranium industry have been included in this study because they may affect the interpretation of the health effects of radiological exposures. In this segment of the industry, ammonia presents the greatest single potential for exposure. Exposures to a variety of other chemicals and gases are possible; however, concentrations are generally 
not at levels thought to be a health hazard. Other chemicals to which workers are exposed include $\mathrm{NO}_{2}-\mathrm{NO} x$, $\mathrm{HF}$, fluorides, and welding fumes.

\subsubsection{Regulatory Aspects}

Historically, AEC and (since 1974) NRC have been responsible for licensing and regulating commercial uranium conversion and fuel fabrication facilities. Conversion facilities must have a source material license to operate. Requirements for the license are given in 10 CFR 40 . Fuel fabrication plants are licensed by NRC to process compounds that contain special nuclear materials. Procedures and criteria which must be met for licensees to "receive title to, own, acquire, deliver, receive, possess, use, and initially transfer special nuclear material" are found in 10 CFR 70. Both conversion and fuel fabrication facilities must periodically renew their operation license and are subject to routine inspections by the NRC. In addition these facilities must comply with the radiation protection standards in 10 CFR 20.

Department of Energy owned- and contractor-operated facilities are regulated by DOE. Such facilities are not formally licensed, but are operated under contract by a private corporation. All contracts to operate DOE facilities contain a health and safety clause which stipulates that the facility will be operated in accordance with DOE orders. It is important to note that a DOE field office may amend DOE Orders to "fit" a particular facility. This means that the types of personnel protection programs at different facilities may vary even though they are all operated for DOE. DOE contractor-operated facilities are routinely audited and appraised by DOE. 


\subsection{GENERAL RADIOLOGICAL HEALTH PRACTICES}

All facilities involved in the production of uranium fuel should follow certain health physics procedures to el iminate unnecessary exposure to radioactive materials and to document radiological conditions. In this report, radiation safety has been divided into four general categories:

- facility monitoring

- exposure control

- exposure evaluation

- record keeping.

The following sections provide an overview of radiological health practices that are common to conversion, enrichment, and fuel fabrication phases of the uranium industry. More detailed information on each phase is provided in sections 3.0 through 5.0 .

\subsection{FACILITY MONITORING}

The most significant pathway of exposure to radioactive materials at uranium fuel production facilities is the inhalation of airborne uranium compounds. Secondary is the exposure to gamma rays from uranium and uranium daughters. This section describes the current practices used to monitor for airborne uranium, uranium surface contamination, and the whole-body dose rate from gamma radiation.

The main objective of the facility monitoring program is to provide a safe working environment. This can be achieved by providing the health physicist with the most accurate information regarding the amount and location of radiological hazards. Samples taken in the workplace should be representative of the actual working environment.

Monitoring and sampling locations and frequency are determined by each company and are included in the license application. Monitoring locations are selected by considering 1) the quantity of radioactive materials in the production process, 2) the potential for release of radioactive materials into the working environment, and 3) the proximity of radioactive material to the worker. 
Air samples are generally taken at or above the breathing zone. Monitoring for beta-gamma radiation is performed one meter above the floor, roughly the height of the reproductive organs. The frequency of monitoring and sampling is determined by the magnitude of the concentration of airborne radioactive materials and the potential for worker exposure.

A discussion of facility monitoring may be divided into three general categories:

- airborne particulate sampling

- surveys for surface contamination control

- external gamma radiation surveillance.

\subsubsection{Airborne Particulate Sampling}

The air in the working environment is monitored and sampled to determine the concentrations of uranium compounds $\left(U_{3} 0_{8}, U 0_{3}, U 0_{2}, U F_{4}\right)$ that are present. A variety of samplers are used, including portable and fixed location air filter pumps and lapel samplers. Lapel and high volume samplers are commoniy used during special maintenance activities and in areas of potential airborne releases not monitored by fixed-location instruments.

The sampling media may be cellulose acetate, glass fiber, or membrane (millipore) air filters, the type used depending on the method of analysis. Two current methods are fluorometry and direct alpha counting. Air concentrations are usually reported in units of microcuries ( $\mu \mathrm{C} i$ ) of activity per milliliter (me) of air.

\subsubsection{Surveys for the Control of Surface Contamination}

Surveys for surface contamination are conducted regularly in all areas where radioactive contamination may be present, since surface contamination increases the likelihood of inhalation or ingestion of small quantities of uranium. Area surveys are also regularly conducted in unrestricted areas such as lunch rooms and administrative offices.

Often, contamination may be detected visually (especially with yellowcake). In instances where it is not visible, contamination is detected using alpha and beta-gamma survey instruments and filter-smear sampling techniques. 
Contamination of less than $4 \mathrm{pCi} / \mathrm{cm}^{2}\left(10 \mathrm{dpm} / \mathrm{cm}^{2}\right)$ indicates good housekeeping and a successful contamination control program (USNRC 1977).

\subsubsection{External Gamma Radiation Surveillance}

External gamma radiation levels at locations throughout the facility are determined by using portable survey instruments or by using thermoluminescent dosimeter chips (TLDs) or film dosimeters. Portable survey istruments such as Geiger-Mueller (GM) counters and scintillation counters (e.g., Micro-R Meter) provide an instantaneous measurment of beta-gamma levels. TLDs or film will provide time-integrated beta-gamma levels. Survey readings are taken and dosimeters are evaluated at regular intervals, which vary from weekly to annual depending on the exposure potential at a given location. Special maintenance tasks frequently require more specific radiation monitoring, but the same types of instruments are used.

Survey results are recorded and maintained according to regulations. Management personnel are required to periodically audit survey data and assure that survey instruments are calibrated regularly.

\subsection{EXPOSURE CONTROL}

The purpose of a radiation protection program is to insure that workers are not exposed to radioactive materials or ionizing radiation at levels that could adversely affect their health. Although recent research has increased the industry's awareness of the hazards of exposure to uranium compounds, it has not established the lower levels of chronic exposure at which no effects are observable. Hence, the concept of maintaining exposures as low as is reasonably achievable (ALARA) forms the basis of radiological safety.

The uranium industry has a record of reducing worker exposures over the years. That reduction has occurred as a result of a four-element exposure control program consisting of:

- design engineering

- use of respiratory protection

- contamination control

- employee training. 


\subsubsection{Design Engineering}

Three general areas are stressed in designing the uranium production facilities to reduce employee exposures to radioactive materials and ionizing radiation: 1) process equipment designed to ensure against leaks or release of powders (containment dependability), 2) dust collection systems, and 3 ) indoor area ventilation and exhaust systems. Therefore, conversion, enrichment, and fuel fabrication processes are all engineered to be performed in closed systems. Dispersible uranium dusts or aeorsols are generally contained except at feed loading and product collection points and during maintenance operations when it is necessary to breach containment.

\subsubsection{Respiratory Protection}

Since the radiotoxicological effects of chronic inhalation of uranium are not well known and the chemical toxicity of uranium compounds taken into the body may be greater than the radiological toxicity, it is always prudent to provide a measure of respiratory protection for uranium workers. Most exposure can be prevented by following a suitable respiratory protection program supervised and enforced by management.

The use of respirators is required during hazardous maintenance operations and at all times in those areas of the plant where controls are insufficient to maintain general air uranium concentrations consistently below allowable limits as given in 10 CFR 20 Appendix B. Facilities should provide training to workers in the proper care, storage, and fitting of respiratory devices. Requirements for respirators are found in Title 29 Code of Federal Regulations Part 1910.134. Regulatory Guide 8.15 (U.S NRC 1976), NUREG-0041 (U.S. NRC 1976) and ANSI Standard 288.2 (ANSI 1980) provide additional guidance.

\subsubsection{Contamination Control}

The purpose of contamination control is to limit the quantities of radioactive materials that may at some time enter the body through ingestion or inhalation. Dust control methods have already been mentioned. Inevitably, tools and machinery, floors, workers' clothing and shoes, and other surfaces near the process equipment will become contaminated with small amounts of 
radioactive material. For example, this could occur in the yellowcake sampling and unloading areas of conversion facilities. These areas are usually washed down with water at regular intervals to recover the product and prevent the uranium from becoming airborne. The objectives of these measures are to prevent the spread of radioactive material from the process area to administrative offices, lunch rooms, laboratories, and to prevent contamination of street clothing and items taken from the mill for repair or disposal.

Overalls or other work clothing should be of is provided and laundered by the plant daily. Change rooms with lockers should be or is located in a buffer zone between the process and administration areas. The worker is usually required to wear clothing and boots supplied by the company, and must change and shower before leaving at the end of the work shift. Where necessary, workers are instructed to change clothing and scrub hands, arms, and face thoroughly before going to lunch.

\subsubsection{Training}

Uranium production facilities are required by the licensing authority to provide a radiological protection training program for all employees who work with or around radioactive materials. New employee orientation should begin before the worker is assigned to potentially hazardous areas. Periodic (usually annual) testing of the employee's knowledge and skills and continued on-the-job training are also required. The facility must issue a description of the training program (including copies of radiological safety instructions given to each employee) when submitting application for an operating license. The following items are included:

- personal hygiene, including on-site washing and showering

- surveying for contamination prior to eating or leaving the plant

- instructions for wearing personnel monitoring devices and respirators

- instructions for good housekeeping and contamination control. 
Since the laborer may not be familiar with ionizing radiation, the basic training program also includes:

- general health effects of routine occupational exposure, overexposure, and chronic exposure to radioactive materials

- emergency procedures

- purpose and use of protective clothing

- description of the company's medical program

- the importance of following instructions and workplace rules.

All uranium facilities have instituted training programs. Some, for example, give 24 class hours of new employee indoctrination with follow-up 8-hour refresher courses (with exams) annually. Each company selects the training program format suited to its own specific needs. The training program is then approved by the regulating agency.

\subsection{EXPOSURE EVALUATION}

Exposures to radioactive sources are estimated 1) from radioactive materials deposited in the body primarily by inhalation and 2) from penetrating radiation emanating from materials outside the body.

The retention, metabolism, and ultimate toxicity of uranium and its associated decay series products depend upon the chemical forms and specific activities of these elements. The chemistry of uranium determines its solubility in body fluids and hence its retention time in body tissues. Although the specific activity of natural uranium is extremely low (1.5 alpha dpm/ $\mathrm{gg}$ ), insoluble forms of uranium may remain in the body for long periods of time and accumulate during periods of chronic exposure. Soluble uranium compounds leave the body more rapidly and may damage kidney cells in the process.

Table 2.1 presents a classification scheme for solubilities of uranium compounds in the lung (ICRP 1966) along with selected uranium compounds in each classification (AEC 1974, Kalkwarf 1979). 
IABLE 2.1. Solubility Classification of Selected Uranium Compounds Class D - Soluble (transported) compounds - solubility half-life (time for half of the compound to be dissolved in lung fluids) of 1 to 10 days.

$\begin{array}{ll}\text { Ammonium diuranate (ADU) } & \left(\mathrm{NH}_{4}\right)_{2} \mathrm{U}_{2} \mathrm{O}_{7} \\ \text { Uranium hexafluoride } & \mathrm{UF}_{6} \\ \text { Uranium trioxide } & \mathrm{UO}_{3} \\ \text { Uranyl acetate } & \mathrm{UO}_{2}\left(\mathrm{C}_{2} \mathrm{H}_{3} \mathrm{O}_{2}\right)_{2} \\ \text { Uranyl chloride } & \mathrm{UO}_{2} \mathrm{Cl}_{2} \\ \text { Uranyl fluoride } & \mathrm{UO}_{2} \mathrm{~F}_{2} \\ \text { Uranyl nitrate } & \mathrm{UO}_{2}\left(\mathrm{NO}_{3}\right)_{2} \\ \text { Uranyl sulfate } & \mathrm{UO}_{2} \mathrm{SO}_{4}\end{array}$

Class W - moderately soluble (slowly-transportable) compounds - estimated solubility half-life of 10 to 100 days inclusive.

Uranium dioxide

Uranium tetroxide

$\mathrm{UO}_{2}$

$\mathrm{UO}_{4}$

Class Y - relatively insoluble (very slowly-transportable) compounds - estimated solubility half-life of greater than 100 days.

$\begin{array}{ll}\text { Uranium aluminide } & \mathrm{UAl}_{\mathrm{x}} \\ \text { Uranium carbide } & \mathrm{UC}_{2} \\ \text { Uranium dioxide (high-fired) } & \mathrm{UO}_{2} \\ \text { Uranium oxide } & \mathrm{U}_{3} \mathrm{O}_{8} \\ \text { Uranium tetrafluoride } & \mathrm{UF}_{4} \\ \text { Uranium-zirconium alloy } & \mathrm{UZr}\end{array}$

Personnel dosimeters (TLDs or film badges) permit determination of external exposures to gamma radiation. Internal exposure is estimated by determining the quantity of radioactive material present in the body at the time of intake and the length of time it remains in the body. The radioactive materials are measured using bioassay of excreta analysis (e.g., urinalysis) or in-vivo lung counting. Urinalysis is a common method of determining whether uranium has 
been taken into the body, but it cannot be relied upon alone. If done less frequently than biweekly, an accidental inhalation of a uranium compound could go undetected. For this reason, combinations of other techniques may be used as well, including regular facility air monitoring and recording of worker time spent in the monitored area (MPC-hrs), (a) worker lung counting, fecal sampling, and nasal smears.

The following sections provide a brief review of bioassay programs and external gamma personnel monitoring programs at uranium production facilities.

\subsubsection{Bioassay Programs}

Bioassays may be either direct or indirect assessments of radioactive materials in the body. One direct bioassay is chest counting. Indirect assessments include measurement of the radioactivity content of excreta (urine and feces), blood, breath or tissue samples. An excreted sample gives an indication of the amount of radioactive material that has left the body. To determine body burdens from urinalysis or analysis of feces, one must turn to accepted biological excretion models and calculate back to the body burden that would have resulted in the observed excretion. The models and assumptions used to evaluate uranium depositions in workers are found in several ICRP publications (ICRP 1966, 1972, 1977, and 1979).

A minimum bioassay program may be instituted if the quarterly air sampling shows that the average airborne uranium concentration in the worker's breathing zone does not exceed $10 \%$ of the appropriate Derived Air Concentration (DAC) given in Appendix $B$ of 10 CFR Part 20, and if the maximum result obtained to calculate the average does not exceed $25 \%$ of the DAC. The minimum bioassay program consists of an annual or semiannual urine sampling of all workers and a more frequent sampling protocol for those who may be exposed to higher-thanaverage uranium concentrations (U.S. AEC 1974a, U.S. AEC 1974b).

(a) MPC-hrs represent the product of a worker location air concentration and the time spent by the worker in that area.11 For example, if the average uranium concentration in air were $5 \times 10^{-11} \mu \mathrm{Ci} / \mathrm{ml}(0.5 \mathrm{MPC})$ at a given work location and the worker spent 8 hours in that location, his exposure would be 4 MPC-hours. The maximum allowable MPC-hrs/8-hr work day is 8 MPC-hrs. 


\subsubsection{Urinalysis}

Frequency of urinalysis is an important consideration. Delays between intake and sampling beyond four days are undesirable because uranium may be excreted during the delay, and thus go undetected. Workers in areas with a potential for inhalation of soluble uranium compounds generally give urine samples biweekly to reduce the possibility of an undetected intake.

Laboratory methods for determining uranium concentrations in the urine are optional with the facility, and are not specified in the regulatory guides. Ul traviolet fluorometry (Harley 1972) is most often the method of choice. Samples may be analyzed onsite or sent to a vendor. Federal guidance for corrective actions based on urinalyses is provided in U.S. AEC (1974b) and U.S. NRC (1978) (see Table 2.2).

\subsubsection{Lung Counting}

A few uranium fuel cycle facilities have the capability and equipment to perform on site in-vivo chest counting. The service is also available from specialized subcontractors, one of which is equipped with mobile whole-body counting laboratories.

The in vivo measurement for internally deposited uranium is performed using sodium iodide (thallium activated) solid crystal or phoswich detectors and a multichannel analyzer. Since the alpha emissions of ${ }^{238} U$ do not penetrate the chest wall, the measurement of uranium in the lungs is based upon detection of either the $186 \mathrm{keV}$ photon from ${ }^{235} \mathrm{U}$ or the two photons from ${ }^{234} \mathrm{Th}$ at $63 \mathrm{keV}$ and $93 \mathrm{keV}$. Depending upon the source of the uranium that has potentially entered the body, the quantity of isotope ${ }^{235} U$ may vary depending upon whether the uranium is enriched, depleted, or of a natural abundance. The uranium material will contain a natural abundance $(0.72 \%)$ of ${ }^{235} \mathrm{U}$. The photon for chest counting measurements will usually be the ${ }^{235} \mathrm{U}$ photon if the enrichment is greater than $2 \%$. In other situations, the counting procedure must be based on the type of measuring equipment available, possibility of external contamination, and external background levels.

Federal guidance for correction. actions based on whole-body counts is provided in U.S. AEC (1974b) and U.S. AEC (1978) (see Table 2.3). 
TABLE 2.2. Corrective Actions Based on Urinary Uranium Concentration Results (U.S. NRC 1978)

Urinary Uranium Concentration

Less than $15 \mu \mathrm{g} / \ell$

15 to $30 \mu \mathrm{g} / \mathrm{\ell}$

Greater than $30 \mu \mathrm{g} / \mathrm{l}$

Greater than $30 \mathrm{\mu g} / \mathrm{l}$ for four consecutive specimens or greater than $130 \mu \mathrm{g} / \ell$ for any specimen

\section{Interpretation}

Uranium confinement and air sampling capabilities are adequate.

Uranium confinement and perhaps air sampling capabilities do not provide an adequate margin of safety.(a)

(a) Unless the result was anticipated and caused by conditions already corrected.

\section{Uranium confinement and perhaps air sampling capabilities are not acceptable. $(a)$}

Possibility of kidney damage to worker.
Actions

None

1. Confirm results (repeat urinalysis).

2. Determine why air samples were not representative and did not warn of excessive concentrations of airborne uranium. Make corrections.

3. Identify the cause of airborne uranium and initiate additional control measures.

4. Determine whether other workers could have been exposed and perform bioassay measurements for them.

5. Consider work assignment limitations to ensure the worker does not exceed urinary uranium concentration of $30 \mu \mathrm{g} / \mathrm{l}$.

1. Take the actions given above for 15 to $30 \mu \mathrm{g} / \mathrm{l}$.

2. Continue operations only if it is virtually certain that no other worker will exceed a urinary uranium concentration of $30 \mu \mathrm{g} / \mathrm{l}$.

1. Take the actions given above.

2. Have additional urine specimen tested for albuminuria. 
TABLE 2.3. Corrective Actions Based on In-Vivo Results (U.S. NRC 1978)

Urinary Uranium Concentration

Below 9 nCi of uranium

9 to $15 \mathrm{nCi}$

More than $16 \mathrm{nCi}$
Interpretation

This result does not necessarily indicate that uranium confinement and air sampling capabilities are confirmed.

Confinement and air sampling capabilities unreliable.(a) Uranium activity in lungs undesirably high. Confinement and air sampling not
acceptable. (a)
Actions

Rely on urinalysis results to determine corrective actions.

1. Confirm result (repeat measurement).

2. Determine why air samples were not representative and did not warn of excessive airborne uranium. Make corrections.

3. Identify the cause of airborne uranium and initiate additional control measures.

4. Determine whether other workers could have been exposed and perform bioassay measurements for them.

5. Consider work assignment 1 imitations that will permit the lung burden to be reduced through natural elimination; ensure that the lung burden does not exceed $16 \mathrm{nCi}$.

1. Take the actions listed above for 9 to $16 \mathrm{nCi}$.

2. Establish work restrictions for affected workers. (Normally, workers with a lung burden greater than $16 \mathrm{nCi}$ are not allowed by their employer to resume work in airborne activity areas until the burden is reduced to less than $9 \mathrm{nCi}$.)

3. Perform individual case studies (bioassays) for affected workers.

4. Continue operations only when it is virtually certain no additional workers will exceed $16 \mathrm{nCi}$.

(a) Unless the result was anticipated and caused by conditions already corrected. 


\subsubsection{External Exposures}

There are two basic methods for determining external gamma radiation exposure at uranium production facilities. One method involves providing employees with personnel dosimeters which integrate each individual's external exposure to gamma radiation on the job. These may consist of radiosensitive film (film badges) or thermoluminescent dosimeter (TLDs). The second method used infrequently calculates employee exposures by using area monitoring data for external radiation and the time spent by each employee in the particular working area. Employee exposure to penetrating external radiation is 1 imited to 5 rem per year, or approximately 2.5 mrem per working hour (10 CFR 20).

\subsubsection{Record Keeping}

Title 10 Code of Federal Regulations Part 20.401 requires each 1 icensed uranium conversion and fuel fabrication facility to maintain careful records showing radiation exposures of all individuals for whom personnel monitoring is required. These records shall be kept until the NRC authorizes disposition. Also, the facilities must maintain results of radiation surveys, monitoring, and dispositions of radioactive materials. This includes bioassay results. Records must be prepared according to recommendtions of the American National Standards Institute (ANSI No. 13.6, 1966, "Practice for 0ccupational Radiation Exposure Records Systems") and must be kept on file for at least two years. Most facilities, however, will maintain these records indefinitely. Enrichment facilities which are regulated by the Department of Energy must keep their personnel exposure records for 75 years (DOE Order 1324.2, Chapter 5).

A licensed nuclear facility must immediately report to the regulatory agency any loss, theft, or accidental release of radioactive materials. In addition, any overexposures, or conditions that could expose individuals to radiation levels in excess of maximum permissible limits must be reported immediately. The facility must also file, with the regulatory agency, a worker termination report which summarizes the individual's radiation exposure history for the period of employment. Records and files are inspected annually by the regulatory agency for compliance to the 10 CFR Part 20 or DOE Manual chapter 0524. 


\subsection{CONVERSION FACILITIES}

Conversion is a chemical process during which yellowcake is purified and converted to volatile uranium hexafluoride $\left(U_{6}\right)$. Two commercial conversion facilities exist in the United States today, Allied Chemical Corporation located in Metropolis, Illinois and Kerr-McGee Corporation in Gore, Oklahoma. Allied Chemical began operation in 1959 and Kerr-McGee began operation in 1970 . The total production capacity of these facilities is approximately 18,000 tons $(16,300 \mathrm{t})$ of uranium per year. The two facilities employ a total of approximately 350 workers in uranium process areas. Uranium registry personnel visited both facilities.

\subsection{PROCESS DESCRIPTION}

Two processes are used to purify and convert yellowcake $\left(\mathrm{UO}_{3}, \mathrm{U}_{3} \mathrm{O}_{8}\right.$, and ammonium diuranate [ADU], or a combination of the three) to uranium hexafluoride $\left(U F_{6}\right)$. These are solvent extraction-fluorination, and fluorinationfractional distillation. The processes are commonly referred to as "wet" and "dry" processes, respectively. In the wet process, the uranium is purified by

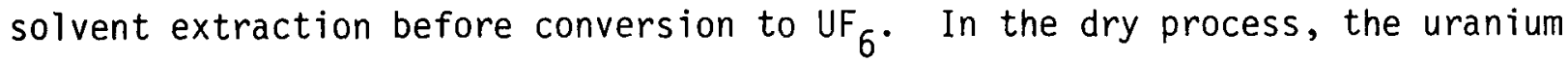
is purified by fractional distillation after conversion. As shown in Figure 3.1, the major steps in each process are sampling, feed preparation, and conversion and purification.

\section{1 .1 Sampling}

The yellowcake arrives at the conversion plants in 55-gal. drums. It is then analyzed for chemical and physical characteristics which could affect the conversion process. The uranium content of the yellowcake is verified. The yellowcake arrives in a variety of physical forms which range from fine dry powder to coarse granules with a wide range of moisture content. Yellowcake from different drums or batches is blended to obtain uniform chemical and physical properties. If a high sodium content is detected in the feed material, it must be sent through a sodium removal process prior to blending and sampling. 
SAMPLING

FEED

CONVERSION

PURIFICATION

1

DRY

PROCESS

\begin{tabular}{|c|c|c|c|c|c|c|}
\hline $\begin{array}{l}\text { YELLOWCAKE } \\
\text { BLENDING \& }\end{array}$ & CALCINATION & $\mathrm{U}_{3} \mathrm{O}_{8}-\mathrm{REDUCTION}$ & $U F_{6}$ & DISTILLATION & $\mathrm{UF}_{6}$ & \\
\hline SAMPL & & - FLUORINATION & GAS & CONDENSATION & LIQUID & PACNAGUINU \\
\hline
\end{tabular}

ڤึ

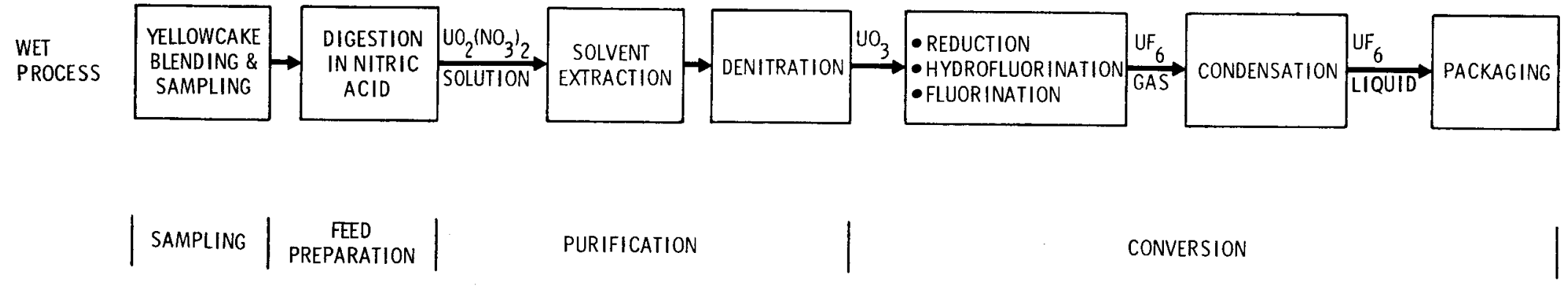

FIGURE 3.1. Flow Diagram of Conversion Processes 
The sampling takes place in a high bay area separated from facilities in which the rest of conversion occurs. Drums of yellowcake are uncapped, elevated, and inverted. The feed material is dumped into a mixing hopper or blender. The drums are then vacuumed. From the hopper, the yellowcake is allowed to fall past a stream sampler and back into empty drums on the ground floor. Refilling occurs in an area with controlled air flow (i.e., at the dry process site, refilling occurs in a large open-face hood). The samples are then analyzed in-house; the mill from which the feed originated or an independent laboratory may verify the analysis.

Uranium feed material may arrive in the form of ADU slurry or UF 4 slurry produced as a phosphate by-product. When this occurs, slurry is pumped into receiving tanks from which it is sampled. Only the wet process facility can handle slurries.

\subsubsection{Feed Preparation}

At the point where yellowcake enters the feed preparation process, drums from several different shipments are selected and combined to form a feed with the most desirable characteristics. As with sampling, the area where yellowcake is loaded into the feed preparation process is separate from the other process areas for dust control. The empty drums are removed and cleaned by shot blasting.

In the dry process, feed preparation comprises several steps that produce a material with the proper chemical and physical characteristics. Yellowcake is passed through a magnetic separator into a hopper that feeds a calciner. Calcination dries the yellowcake and converts many of the uranium compounds to uranium oxide $\left(\mathrm{U}_{3} \mathrm{O}_{8}\right)$. The feed material, after being crushed and blended for uniform mixture, is then remoistened and formed into pellets, called "mudballs." The pellets are dried, precrushed, passed through a size separator and deposited in the prepared feed hoppers. The feed is then ready for the conversion process.

In the wet process, feed preparation consists of yellowcake digestion in nitric acid, which requires approximately eight hours and takes place in large 
tanks. The resulting prepared feed is a uranyl nitrate solution $\left[\mathrm{UO}_{2}\left(\mathrm{NO}_{3}\right)_{2}\right]$. At this point in the system, the wet process will also accept $\mathrm{U}_{3} \mathrm{O}_{8}$ slurry from in situ, heap-leaching, phosphate by-product facilities.

\subsubsection{Conversion and Purification}

In the dry conversion process, feed preparation is followed by the conversion of $\mathrm{U}_{3} \mathrm{O}_{8}$ to $\mathrm{UF}_{6}$ and purification. In the wet process, feed preparation is followed by purification and then conversion. The two purification and conversion processes are described separately because of this difference in process sequence (Figure 3.1).

\subsubsection{Dry Process}

The $\mathrm{U}_{3} \mathrm{O}_{8}$ powder is first processed with hydrogen gas (from cracked ammonia) through a fluidized-bed reductor for intermediate conversion to uranium dioxide powder $\left(\mathrm{UO}_{2}\right)$. Further conversion to uranium tetrafluoride $\left(\mathrm{UF}_{4}\right)$ is accomplished in a series of fluidized-bed hydro-fluorinators into which $\mathrm{UO}_{2}$ and $\mathrm{HF}$ gas are introduced. Final conversion takes place in a fluidized-bed fluorinator where $U F_{4}$ powder and $F_{2}$ gas are combined to form $U F_{6}$.

Uranium hexafluoride is purified in a series of fractional distillation columns. Here impurities including molybdenum and vanadium are boiled out; others (including uranium daughters) are collected as ash at the base of the columns. The product is $99.99 \%$ UF $_{6}$.

The UF 6 product is condensed and drained as a liquid into steel cylinders. When ful1, these cylinders are placed in steam chests where the UF 6 is maintained as a liquid and homogenized by cylinder rotation. After removal of a sample of the $U_{6}$, the cylinder is cooled, weighed, and placed in an outdoor storage yard to await shipment.

\subsubsection{Wet Process}

The uranyl nitrate solution from the feed preparation phase is purified by solvent extraction in pumper-decanters using 30\% tributyl phosphate in hexane. Next, the uranium-loaded solvent is scrubbed with acidified water to remove residual impurities. This operation is followed by re-extraction of the uranyl nitrate into the aqueous phase. Before the uranyl nitrate-water solution is 
concentrated, it is first scrubbed with hexane to remove tributyl phosphate. The solution is then concentrated in a primary and secondary evaporation system. The uranyl nitrate hexadrate is denitrated to uranium trioxide $\left(\mathrm{UO}_{3}\right)$ powder in a stirred trough. Finally, the $\mathrm{UO}_{3}$ powder is pulverized in a hammer mill.

The conversion of $U_{3}$ to $U_{6}$ is accomplished using the same techniques described for the dry purification and conversion process with the exception that fluorination takes place in an 8-in. diameter, $10 \mathrm{ft}$ long flamer tower. The $U_{6}$ then passes through sintered Monel filter tubes to remove ashed materials.

\subsection{RADIOLOGICAL EXPOSURES}

0ccupational radiation exposures are directly related to the steps involved in the conversion of yellowcake to volatile $U_{6}{ }_{6}$. The exposures may occur during routine continuous operations, periodic maintenance, or as a result of accidental loss of containment.

The potential exists for exposure to a variety of uranium compounds at various locations in the conversion facilities. Yellowcake, although commonly referred to as uranium oxide $\left(\mathrm{U}_{3} \mathrm{O}_{8}\right)$, is often a mixture of several chemical complexes. Depending upon the operating characteristics of the uranium mill, the following compounds may be present in varying concentrations:

- uranium oxide $-U_{3} 0_{8}(a)$

- uranium trioxide $-\mathrm{UO}_{3}$

- ammonium diuranate - $\left(\mathrm{NH}_{4}\right)_{2} \mathrm{U}_{2} \mathrm{O}_{7}$

- sodium diuranate - $\mathrm{Na}_{2}\left(\mathrm{U}_{2} \mathrm{O}_{7}\right)$.

In addition to uranium, the unpurified yellowcake contains radium, thorium, and other decay products. Table 3.1 lists the typical constituents of yellowcake. In the dry process, these constituents remain in the process until the distillation step where they are collected as ash at the base of the fractional distillation columns. The wet process removes the impurities and daughters in the solvent extraction step, although low concentrations of daughters will (a) $\mathrm{U}_{3} \mathrm{O}_{8}$ - chemically known as uranium octoxide; however, generally referred
to as uranium oxide in the uranium industry. 
TABLE 3.1. Constituents of Typical Yellowcake (Sears et al. 1977)

\begin{tabular}{|c|c|}
\hline Constituent of Feed & Concentration (w \\
\hline Uranium (U) & $\begin{array}{c}73.53 \\
\text { (wt } \%, \text { U basis) }\end{array}$ \\
\hline \multicolumn{2}{|l|}{ Impurities } \\
\hline Ammonium $\left(\mathrm{NH}_{4}^{+}\right)$ & 3.09 \\
\hline Sodium $(\mathrm{Na})^{4}$ & 2.41 \\
\hline Silica $\left(\mathrm{SiO}_{2}\right)$ & 1.2 \\
\hline Sulfate $\left(\mathrm{SO}_{4}^{2-}\right)$ & 2.94 \\
\hline Arsenic (As) & 0.06 \\
\hline Boron $(B)$ & 0.1003 \\
\hline Calcium (Ca) & 0.19 \\
\hline Carbonate $\left(\mathrm{CO}_{3}{ }^{2-}\right)$ & 0.31 \\
\hline $\begin{array}{l}\text { Chloride, bromide, iodide } \\
\left(\mathrm{Cl}^{-}, \mathrm{Br}^{-}, \mathrm{I}^{-}\right) \text {calc. as } \mathrm{Cl}^{-}\end{array}$ & 0.07 \\
\hline Fluoride $\left(F^{-}\right)$ & 0.01 \\
\hline Iron $(\mathrm{Fe})$ & 0.38 \\
\hline Molybdenum (Mo) & 0.10 \\
\hline Phosphate $\left(\mathrm{PO}_{\Delta}^{3-}\right)$ & 0.26 \\
\hline Potassium $(K)$ & 0.13 \\
\hline Vanadium (V) & 0.12 \\
\hline Water $\left(\mathrm{H}_{2} \mathrm{O}\right)$ & 1.91 \\
\hline Extractable organics & 0.05 \\
\hline Nitric acid-insoluble uranium & 0.01 \\
\hline
\end{tabular}

build in during the later process steps. These daughters, most notably ${ }^{234} \mathrm{Th}$, will be removed in the flamer tower ash.

The greatest potential for occupational radiation exposure in conversion facilities is the inhalation of airborne uranium compounds. Inhalation is most likely to occur during the emptying and refilling of yellowcake drums in the sampling area, the removal of ash waste following the purification phase, and maintenance activities throughout the facilities. External exposures are a secondary concern. Annual external whole-body doses to conversion workers are well below the $5-\mathrm{rem} / \mathrm{yr}$ limit set by 10 CFR 20 . In 1975, doses at conversion 
facilities averaged 0.22 rem, with no doses exceeding 2 rem (Cool 1978). Table 3.2 presents external gamma doses for the years 1962, 1969, 1971, and 1973 at one facility.

The conversion work force is approximately $60 \%$ production, $40 \%$ maintenance. Less than $10 \%$ of the production force works in the sampling plant, where there is a potential for inhaling yellowcake from emptying drums. Because of the nature of their work, maintenance personnel have the potential for exposure to a variety of uranium compounds.

The following sections provide a review of radiological exposures for each phase of the conversion process.

\subsubsection{Sampling}

As mentioned previously, inhalation of yellowcake is most likely to occur during uncapping, emptying, vacuuming, and refilling of yellowcake drums in the sampling area. Although a lid is placed over the open drum prior to dumping, the yellowcake is often extremely fine and powdery, thus making dust control difficult. Jostling of the drums while uncovered can result in dispersion of yellowcake dust. Drum vacuuming is a dusty operation performed with a handheld vacuum hose. After the sample is obtained and the drums are refilled, improper sealing of the lid or removal of this lid before dust inside the drum has settled can lead to additional releases. The opening and cleaning of sampling equipment between each yellowcake shipment to avoid cross contamination is another source of potential airborne uranium. General area air

TABLE 3.2. Typical External Gamma Doses to Workers at a
Conversion Facility

$\begin{array}{lcc}\text { Year } & \begin{array}{c}\text { Average Gamma Dose } \\ \text { (rem) }\end{array} & \begin{array}{c}\text { Maximum Gamma Dose } \\ \text { (rem) }\end{array} \\ 1962 & 0.157 & 1.16 \\ 1969 & 0.148 & 1.07 \\ 1971 & 0.133 & 1.70 \\ 1973 & 0.090 & 1.14\end{array}$

(a) Data taken from Allied Chemical (1975). 
concentrations in the drum dumping area of the sampling plant are in the range of $50 \%$ of the allowable limit (10 CFR 10, Appendix B), with locally higher concentrations. These are the highest concentrations found in the conversion plant. Because of the potential for high airborne uranium levels certain operations and areas within the sampling plant (e.g., drum dumping area) require the use of respiratory protection.

The primary source of external exposure in the sampling area would be from routine handling of yellowcake drums. Dose rates at contact on the drums are on the order of $4 \mathrm{mrem} / \mathrm{hr}$. However, workers spend little time in contact with the drums; therefore, it is not a significant source of external exposure.

\subsubsection{Feed Preparation}

The first step in feed preparation for both the wet and dry process involves drum unloading operations similar to those described for the sampling process. The potential for occupational exposure to external radiation and airborne uranium is also similar.

Although the feed preparation operations in the dry process are characteristically dusty, once the yellowcake is loaded into the system it is contained within the process equipment thus reducing the potential for exposure to airborne uranium. There are locations in the process where contact with the feed material is possible via inspection hatches. At these points negative system pressure is maintained to prevent significant releases of material. As long as the process equipment and air flow systems are operating properly, the release of uranium into the breathing atmosphere is negligible. Following calcination, the feed material consists of uranium oxide powder $\left(U_{3} O_{8}\right)$ along with uranium daughters and other impurities.

In the wet process, uranium is in a uranyl nitrate solution with little potential for airborne releases. Air concentrations of uranium in the digestion and denitration areas average between 10 to $20 \%$ of the 10 CFR 201 imit.

\subsubsection{Conversion and Purification}

The conversion and purification phases are reversed for the two processes. The dry process converts $U_{3} 0_{8}$ powder to $U_{6}$ prior to uranium purification; the wet process purifies the uranium and then converts the $\mathrm{UO}_{3}$ powder to $\mathrm{UF}_{6}$. 
Conversion and purification phases of both the dry and the wet process occur in enclosed systems with little potential for inhalation exposures except during ash removal. In the dry process, all impurities and uranium daughter products are collected as ash in drums at the base of the fractional distillation columns. There is a potential for material to become airborne during the manual removal, emptying, and replacement of drums. In the wet process, ash accumulates in drums at the base of the flame tower and at the base of the sintered Monel filters that follow the flame tower. These drums are located within two enclosures, one around the base of the flame tower and another around the filters. As the drums become ful1, the enclosures must be entered and the drums manually removed. At the base of the flame tower, the material found and recycled is primarily unreacted $U_{4}$, while the ash below the filters is made up of uranium daughters. The concentration of uranium daughters is less in the wet-process ash, since they are removed in the solvent extraction phase and would have little time to build in.

External gamma radiation levels in the conversion and purification phase can be significant. For example one facility reported maximum readings of $80 \mathrm{mrem} / \mathrm{hr}$ in the fluorination area (U.S. NRC 1978). However, workers spend little time in this area and, therefore, it is not a significant source of external exposure.

\subsubsection{UF $\mathrm{UF}_{6}$ Cylinder Handling}

$U_{6}$ cylinders are filled, shipped to the DOE enrichment plants, emptied, and returned to the purification and conversion facilities for reuse. Residual $U_{6}$ sometimes remains in the cylinders as a result of incomplete emptying at the enrichment plants. These "heels," after the in-growth of uranium decay daughters, can result in exposure rates as high as 100 to $125 \mathrm{mR} / \mathrm{hr}$ at locations on the cylinder surface. The cylinders are periodically steamed out to remove this source of radiation.

\subsection{NONRADIOLOGICAL EXPOSURES}

Nonradiological health exposures are directly related to the steps involved in the conversion of yellowcake to volatile UF $6_{6}$. In the feed preparation phase 
of the wet process, nitric acid is used for digestion of the ore, and potential exposures to $\mathrm{NO}_{2}-\mathrm{NO}_{x}$ gases are possible. One facility maintains the tanks under vacuum, but $\mathrm{NO}_{2}$ occasionally escapes into the room. On the basis of extensive $\mathrm{NO}_{2}$ monitoring, it appears that no chronic $\mathrm{NO}_{2}$ exposure problem exists. The threshold limit value-time weighted average (TLV-TWA) for $\mathrm{NO}_{2}$ is 5 ppm (ACGIH 1980).

In the conversion phase, cracked ammonia is used to reduce the $\mathrm{U}_{3} \mathrm{O}_{8}$ and $\mathrm{UO}_{3}$ to $\mathrm{UO}_{2}$. The use of large quantities of anhydrous ammonia may represent the most significant potential for an exposure. At one facility, ammonia odor was noticeable in the solvent extraction area, but the concentration is reportedly 5 to $10 \mathrm{ppm}$ most of the time. Concentration levels need to reach 125 to $400 \mathrm{ppm}$ before minor throat irritation is noted (Chester et al. 1979). Due to the inherent warning properties of ammonia (pungent odor detectable at 1 to $5 \mathrm{ppm}$ ), it is unlikely that workers would remain in an area long enough to experience a health problem. The TLV-TWA for ammonia in air is $25 \mathrm{ppm}$ (ACGIH 1980).

The hydrofluorinators in the conversion phase present potential exposures to fluorides, hydrogen fluoride, and hydrogen sulfide. At one facility, monthly urinary fluoride analyses are performed for production and maintenance personne1. Exposures to off-gases are thought to occur mainly during accidental leaks.

Other chemicals to which workers in a conversion facility may be exposed include tributyl phosphate and hexane in the solvent extraction area of the purification phase, and fluorine gas generated by the electrolysis of potassium fluoride with a hydrogen fluoride feed in the conversion phase.

\subsection{RADIOLOGICAL HEALTH PRACTICES}

Discussions of facility monitoring, exposure control, and exposure evaluation practices specific to conversion facilities are presented below.

\subsubsection{Facility Monitoring}

The breathing air in the working environment at conversion facilities is routinely sampled for airborne radioactivity. Stationary air samplers located 
throughout the general working areas collect airborne particulates on filter paper. One facility has a total of 63 stationary air samplers; the other has 36 (Allied Chemical 1975, U.S. NRC 1978). The filter papers are removed at the end of each shift and counted for total activity. Portable air samplers are used during maintenance or other nonroutine activities and as breathing zone samplers and to provide correlation checks with the stationary samplers. No provision is made for quantitative real-time indication of high particulate air concentrations. Alarm systems located in one facility rely on manual initiation after visual recognition of high air concentration (e.g., release of $U F_{6}$ ). Results of the air sampling program are maintained for further reference. General background concentrations of radionuclides have been measured between $1 / 10$ and $1 / 2$ MPC values. In one of the plants, an administrative control of $1 / 2$ an MPC was established as an action point for corrective actions while 1/3 MPC levels required reporting.

External gamma radiation fields are measured periodically (usualiy monthiy) at predesignated areas throughout the facility. Portable survey instruments are used for these surveys. Surveys are conducted in areas such as the fluorinator, hydrofluorinator, solvent extraction, and demitration where there is a potential for accumulation of uranium daughter products.

Surface contamination measurements including direct survey meter readings and smear surveys are taken periodically through the facilities. In addition to operating areas, other areas surveyed include lunch rooms, locker areas, offices, and reception areas. In plant operating areas, action levels for promp cleanup and decontaminations are $600 \mathrm{dpm} / 100 \mathrm{~cm}^{2}$ and $2000 \mathrm{dpm} / 100 \mathrm{~cm}^{2}$ smearable alpha contamination for the two facilities (Allied chemical 1975 and U.S. NRC 1978). In lunchrooms, locker areas, and offices, more restrictive action levels of $50 \mathrm{dpm} / 100 \mathrm{~cm}^{2}$ and $500 \mathrm{dpm} / 100 \mathrm{~cm}^{2}$ are defined.

\subsubsection{Exposure Control}

Routine respiratory protection for all workers at conversion facilities is provided by half-face masks with particular filters. These respirators are required to be worn continuously in specified operating areas and during certain nonroutine activities. One facility has an in-plant administrative 
limit of $4 \times 10^{-11} \mu \mathrm{Ci} / \mathrm{m} \ell(40 \% 10$ CFR 20 limit) for requiring respirators. Full-face respirators with particulate canisters or supplied air are also available for use during special operations.

Personnel contamination surveys are performed by employees when leaving radiation areas. Additionally, some controls have been engineered into the process and into various procedures. For example, the entire conversion process is contained in a closed system except at the drum dumping area in the sampling location and the $U_{6}$ sampling location. The entire process line is maintained at negative pressure. Procedural controls include having two people present to break $l$ ine connections and freezing $U_{6}{ }_{6}$ lines and containers before breaking the connections. Processes are physically separate to prevent contamination spread.

\subsubsection{Exposure Evaluation}

Exposure evaluation methods at conversion facilities include bioassay and determination of external gamma exposure. The routine bioassay program requires all workers in uranium process areas to submit urine samples once every two weeks. These samples are analyzed for uranium content $(\mu \mathrm{g} / \mathrm{l})$ using the fluorometric analytical technique. One facility does this analysis onsite, the other sends its samples offsite. The offsite laboratory generally performs analysis within a couple of days upon receipt. Elevated results are immediately reported to the facility by phone. Routine results are sent to the facility in writing approximately two weeks after receipt of the samples. Table 3.3 presents data from one facility on worker urinalysis results during the years 1962, 1969, 1971 , and 1973.

Included in the routine bioassay program are lung counts once every one or two years. These are performed with onsite equipment or by a vendor-supplied mobile whole-body counting laboratory. In 1976, one facility counted 52 workers with results ranging from $0 \pm 0.2$ to $8.8 \pm 1.0 \mathrm{mg} U$-natural (average $0.5 \pm 0.5 \mathrm{mg}$ ) (U.S. NRC 1978). 
TABLE 3.3. Worker Urinalysis Results(a)

\begin{tabular}{lrrrrr} 
& \multicolumn{4}{c}{ Year } \\
\cline { 2 - 6 } & \multicolumn{1962}{c}{} & & $\underline{1969}$ & $\underline{1971}$ & $\underline{1973}$ \\
Number of samples analyzed & 2583 & 2846 & 3036 & 2626 \\
Average concentration $(\mu \mathrm{g} / \ell)$ & 48.1 & 9.9 & 10.6 & 7.1 \\
Number of samples $>25 \mu \mathrm{g} / \ell$ & 948 & 68 & 120 & 41
\end{tabular}

(a) Data from Allied Chemical (1975).

Worker exposure to external gamma radiation is determined by the use of TLD or film badge dosimeters. One facility exchanges dosimeters monthly for employees having a potential exposure greater than $25 \%$ of the 10 CFR limit and quarterly for the other workers. As discussed previously, annual exposures are well within 10 CFR 20 limits.

\subsection{REGULATORY PROCEDURE}

Historically, AEC and (since 1974) NRC have been responsible for licensing and regulating commercial uranium conversion facilities. Conversion facilities must have a source material license to operate. Requirements for the license are given in 10 CFR 40 . Conversion facilities are inspected by NRC, must periodically renew their source material license, and must comply with the radiation protection standards in 10 CFR 20.

Guidance found in 10 CFR Part 40 reflect the current NRC staff position for licensing facilities and assuring worker safety. As such, each applicant must demonstrate that its qualifications (by training and experience) and that all equipment, facilities, and procedures proposed under the license application are adequate to "protect health and minimize danger to life or property." Further, the license application serves as the principal technical communication link between the applicant and the NRC.

The Code of Federal Regulations, Title 10 Part 20 addresses radiation safety specifically and has a stated purpose to "establish standards for [the] protection against radiation hazards arising out of activities under licenses issued by the Nuclear Reguiatory Commission." This purpose is supported by 
regulations that are designed to 1) control possession, use, and transfer of licensed materials by the licensees and 2) help assure that licensees make every effort to maintain personnel exposure to radiation and releases of radioactive materials in effluents as low as is reasonably achievable.

Specific recommendations made in 10 CFR 20 which apply directly to assessment and control of radiation hazards stipulate use of

- suitable measurements for measuring and evaluating intakes from excreted radioactivity,

- engineering and process controls to limit exposure to radiation and airborne radioactive materials, and

- techniques such as increased surveillance, timekeeping, and respiratory protection where engineered controls are unavailable.

Total occupational dose limits established by the NRC are summarized in Table 3.4. A licensee may allow an individual to exceed the quarterly occupational dose limits in Table 3.4 provided that 1) the total occupational dose to the whole body is not greater than $3 \mathrm{rem}, 2)$ the accumulated dose to the whole body does not exceed $5 \cdot(\mathrm{N}-18)$, where $N$ is the individual's age in years at his last birthday, and 3 ) that the individual's dose is documented on Form NRC-4 (or a record containing at least the information required by Form NRC-4).

TABLE 3.4. Total Occupational Dose Limited Per Quarter from 10 CFR 20

Organ of Reference

Whole body, head and trunk; active blood-forming organs; lens of the eye; gonads

Hands and forearms; feet and ankles

Skin of the whole body

\section{Quarterly Dose Limit} (rem)

1.25

18.75

7.5 
For material that may be inhaled, 10 CFR 20 states that no individual may inhale a quantity of radioactive material greater than the quantity that would result from inhalation for 40 hours per week for 13 weeks (or for one week for uranium in soluble form) at the uniform concentration of radioactive material in air shown in Table 3.5 .

Records required by the NRC, as stated in 10 CFR 20, and disposition of these records are summarized in Table 3.6 .

Additiona11y, 10 CFR 20 requires reports to be filed with the NRC to document incidents involving unplanned exposures to radiation or radioactive materials. Specifically, three categories relating to occupational dose are over-exposure to sources of radiation that are external hazards, over-exposure to airborne radioactive materials, and exceeding limits for radiation or concentrations of radioactive materials are exceeded in unrestricted areas. As a minimum, the reports should contain the extent of exposure, exposure estimates, levels of radiation or concentrations of radioactive materials, cause of exposure, corrective steps, exposed individual's name, individual's social security number, and individual's birth date. These reports are on file with NRC for an unspecified amount of time.

In addition to the 10 CFR 20 and 10 CFR 40, the NRC has issued regulatory guides to assist applicants and licensees in complying with the general requirements of the Code of Federal Regulations. These guides were initiated by the AEC in 1970 and were called Safety Guides. Compliance with the regulatory guides themselves is not required; applicants may propose alternatives for new

TABLE 3.5. Maximum Permissible Airborne Concentrations of Uranium and Thorium
Thorium (natural) ${ }^{(a)}$
$6 \times 10^{-11} \mu \mathrm{Ci} / \mathrm{ml}$
Uranium (natural) (a)
$1 \times 10^{-10} \mu \mathrm{Ci} / \mathrm{ml}$

(a) The limits for soluble and insoluble compounds are identical, provided that

$U$ is less than $5 \%$ of the total amount of uranium. 
TABLE 3.6. Required Records and Retention Periods

\begin{tabular}{|c|c|c|}
\hline Record & Contents & Retention Period \\
\hline NRC -4 Form & $\begin{array}{l}\text { Quarterly occupational dose } \\
\text { for an employee }\end{array}$ & (a) \\
\hline NRC -5 Form & Overexposure record & (a) \\
\hline Bioassay Summary & $\begin{array}{l}\text { Bioassay results (including } \\
\text { whole-body counts) of each } \\
\text { employee }\end{array}$ & (a) \\
\hline Survey Results & Radiological conditions & 2 years $(b)$ \\
\hline Personnel Monitoring Results & Personnel dose rates & 2 years $(b)$ \\
\hline Prior Dose Summary & $\begin{array}{l}\text { Signed statement of prior } \\
\text { occupational dose received } \\
\text { in current calendar quarter }\end{array}$ & (a) \\
\hline
\end{tabular}

(a) Records preserved until NRC authorized disposition.

(b) If surveys are used to demonstrate compliance or to evaluate external or internal exposures in the absence of personnel monitoring data, they must be preserved until NRC authorizes disposal.

or existing programs that are not necessarily consistent with the guides. The justification for such alternatives is reviewed by the NRC staff and evaluated on a case-by-case basis.

Regulatory Guides that are pertinent to evaluating occupational exposure in conversion facilities include Regulatory Guide 8.11, Applications of Bioassay for Uranium (AEC 1974), and Regulatory Guide 8.15, Acceptable Programs for Respiratory Protection (NRC 1976a). Regulatory Guide 8.11 does not include recommendations for bioassay of the more highly transportable compounds $U F_{6}$ and $\mathrm{UO}_{2} \mathrm{~F}_{2}$, which are present in conversion facilities.

\subsection{SUMMARY}

The commercial conversion industry consists of two facilities with a total of approximately 350 workers in uranium processes areas. Inhalation of the following uranium compounds is possible: yellowcake, uranium tetrafluoride $\left(\mathrm{UF}_{4}\right)$, uranium dioxide $\left(\mathrm{UO}_{2}\right)$, uranium trioxide $\left(\mathrm{UO}_{3}\right)$, and uranyl fluoride 
$\left(\mathrm{UO}_{2} \mathrm{~F}_{2}\right)$ which is formed when $\mathrm{UF}_{6}$ reacts with moisture in the atmosphere. Activities with the greatest potential for inhalation exposures include yellowcake sampling, waste removal, and maintenance. The workers in the yellowcake sampling area, those engaged in waste removal and maintenance personnel respectively constitute $<10 \%,<5 \%$, and $\sim 40 \%$ of the work force.

Various health practices are employed to assure that exposures to various radiological and nonradiological substances are minimized. External gamma doses to workers are maintained well within the federal 1 imits of $5 \mathrm{rem} / \mathrm{yr}$. These health practices include facility monitoring for airborne and surface contamination, use of respirators, and personnel surveys for contamination. Routine exposure evaluations are also conducted.

Regulatory guidelines set by federal agencies are designed to ensure proper safety measures and adequate documentation. 


\subsection{ENRICHMENT FACILITIES}

Uranium is enriched for both commercial and government use at three government-owned and contractor-operated enrichment facilities located at Oak Ridge, Tennessee; Paducah, Kentucky; and Portsmouth, Ohio. The Oak Ridge and Paducah facilities were visited by Registry personnel. Enrichment is a gaseous diffusion process that increases the ${ }^{235} \mathrm{U}$ concentration of the $\mathrm{UF}_{6}$ feed material by selectively removing ${ }^{238} \mathrm{U}$. In addition to enrichment operations, activities at the three sites have included the conversion of $\mathrm{UO}_{3}$ to $\mathrm{UF}_{6}$, $\mathrm{UF}_{6}$ to $\mathrm{UF}_{4}$, and $\mathrm{UF}_{4}$ to metal, and decontamination and maintenance of diffusion equipment.

All three plants received natural $U_{6}{ }_{6}$. The Kentucky plant also received depleted $U F_{6}$ from the other two plants and returned to them enriched $U F_{6}$ in the range of $0.9 \%$ to $2.0 \%{ }^{235} \mathrm{U}$. The end product of the Tennessee plant is up to $5 \%$ enriched $U_{6}$ for commercial use. The Ohio plant produces both $4 \% \mathrm{UF}_{6}$ for commercial use and $>90 \%$ enriched $U_{6}$ for military and research uses. All three plants produce tailings of $0.2 \% 235^{6}$.

More than 10,000 workers are employed at the three enrichment plants. Of these, only about 19\% (about 2000) of the work force have a potential for exposure to uranium.

\subsection{PROCESS DESCRIPTION}

Enrichment facilities receive $U_{6}$ in solid form stored in large steel cylinders from the conversion plants (see Figure 4.1). The cylinders are weighed and the contents are then liquified by heating and sampled for uranium content. All connections to the $\mathrm{UF}_{6}$ cylinders are made using a section of tubing with appropriate fittings referred to as a "pigtail." The cylinders are cooled to solidify the UF 6 before transfer to the cascade facilities.

At the cascade facility the cylinder is heated transforming the UF 6 to gas. The UF 6 gas is loaded into the enrichment cascade. The cascade is a series of many stages of gaseous diffusion equipment. Each stage consists of a converter containing the diffusion barrier and a compressor that pressurizes 

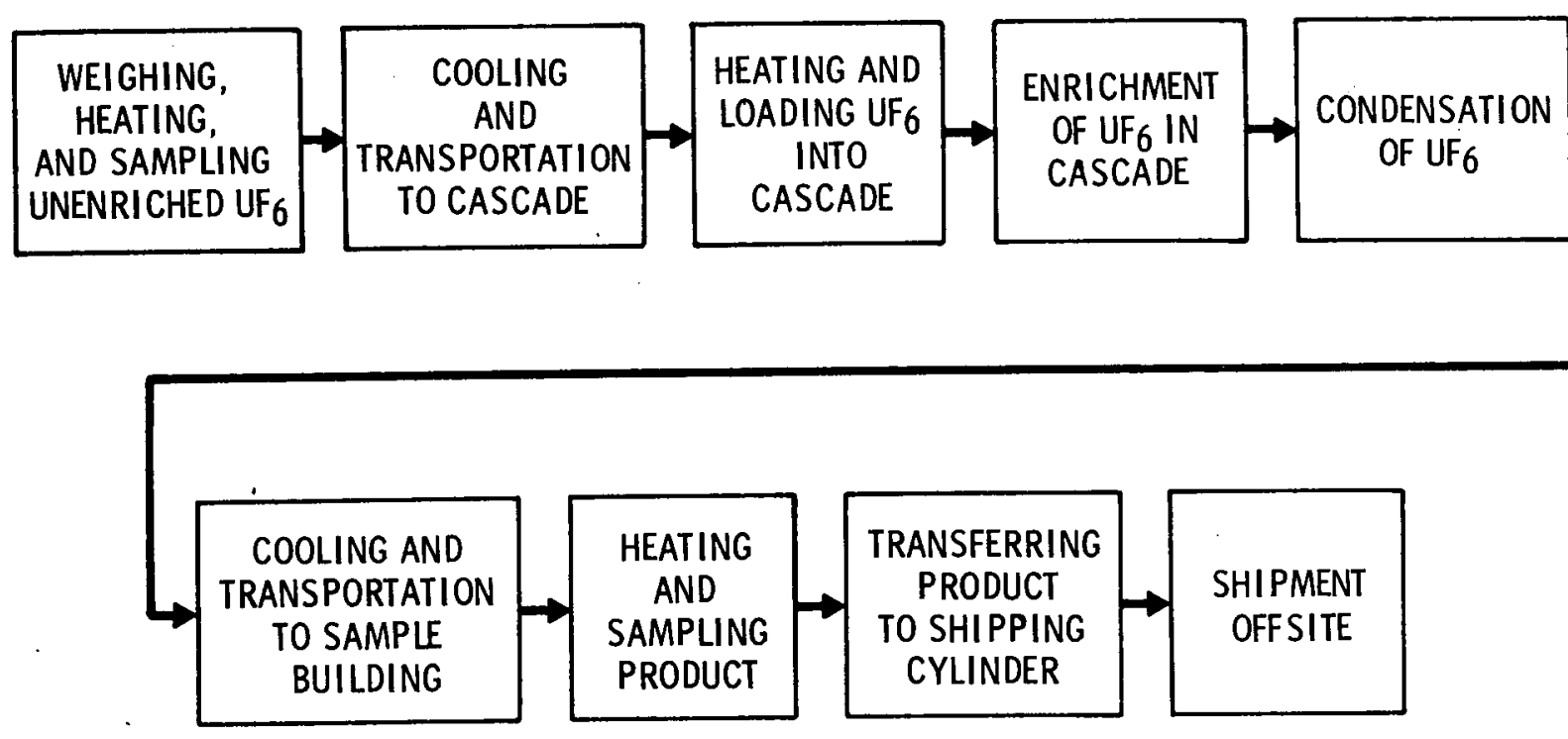

FIGURE 4.1. Flow Diagram of Enrichment Process

the enriched stream from the previous stage, creating a pressure differential across the carrier in the next converter. This pressure differential enhances the diffusion of ${ }^{235} \mathrm{UF}_{6}$ across the barrier. Although the $\mathrm{UF}_{6}$ is pressurized with respect to the barrier, it is still at much less than atmospheric pressure. The $\mathrm{UF}_{6}$ is enriched in ${ }^{235} \mathrm{U}$ content because the ${ }^{235} \mathrm{UF}_{6}$ diffuses through the cascade barrier more rapidly than ${ }^{238} \mathrm{UF}_{6}$. Because the difference in diffusion rates of ${ }^{235} U$ and $238 U$ is very small, many diffusion stages are required to achieve the desired enrichment. This process requires very large and expensive facilities. For example, the Oak Ridge Gaseous Diffusion Plant consists of 4384 stages contained in five buildings covering more than 100 acres.

When the proper enrichment is reached, the $U_{6}$ is drained as a liquid into large steel cylinders. The $\mathrm{UF}_{6}$ is liquified by compression of the $\mathrm{UF}_{6}$ gas from the enrichment cascades. After condensing, the liquid $U_{6}$ is allowed to flow into the cylinder. Both the product and the tails are drained to multi-ton cylinders. The end product $\mathrm{UF}_{6}$ cylinder is then transported to another location 
where the product is reheated, sampled, and transferred to shipping cylinders in preparation for shipment offsite.

When maintenance is required, cascade operations continue while the equipment requiring maintenance is valved off from the remainder of the system. The equipment is then evacuated and purged with air to remove UF 6 before being disconnected. The openings are sealed with plastic and the equipment is removed for decontamination and repair in the maintenance facilities.

\subsection{RADIOLOGICAL EXPOSURES}

Occupational exposures to radiation are directly related to the enrichment process steps. Exposures may occur during some routine operations, periodic maintenance, or as a result of accidental loss of containment. The primary internal radiation hazard of the plants is from an unanticipated release of $\mathrm{UF}_{6}$. External radiation exposures result primarily from handling of $\mathrm{UF}_{6}$ cylinders.

During the sampling process, workers routinely come in contact with UF 6 feed cylinders received from the conversion plants. Empty feed cylinders may have surface dose rates as high as $100 \mathrm{mR} / \mathrm{hr}$ due to buildup of uranium decay products (referred to as "heel"). These cylinders, which are reused for shipment of $U_{6}$ from conversion to enrichment plants, are periodically cleaned to remove the residual heels.

A potential for internal deposition of uranium exists during sample taking. During this operation the cylinder is heated to allow removal of the UF 6 as a liquid. Sample cylinders are connected to the UF 6 feed cylinders below the liquid level and evacuated (along with the connecting piping and "pigtail") prior to sample withdrawal. Following collection of the sample, the pigtail is again evacuated to remove residual $U_{6}$. Should any $U_{6}$ be retained in the pigtail, as has occurred in the past, it will be released to the building where it forms $\mathrm{UO}_{2} \mathrm{~F}_{2}$ and $\mathrm{HF}$. Ventilation is provided in the pigtail area to remove this airborne material. Respiratory protection is also often required when making or breaking a pigtail connection. 
The cylinders are transported to an area for loading into the cascade. The procedure for loading $\mathrm{UF}_{6}$ into the cascade is similar to withdrawing a sample except the pigtail connection is made above the riquid level in the cylinder to obtain $U_{6}$ gas. The potential exists for exposure to residual material held in the pigtail when disconnected. Once the UF 6 has been introduced into the cascade there is very little potential for either internal or external routine radiation exposure. The cascade process is completely enclosed and operates under a vacuum. During operation, there is little or no occupancy of the cascade buildings. Some uranium daughters may build up inside the gaseous diffusion equipment, but the large surface area results in very low dose rates.

The product of the enrichment process is unloaded into a large cylinder as liquid $U F_{6}$ through pigtails. Again, these pigtails represent a potential for release of UF 6 gas when disconnected from the cylinder.

External radiation doses may also be received from handling the product $U_{6}$ cylinder. Surface exposure rates of up to $500 \mathrm{mR} / \mathrm{hr}$ may be encountered due to buildup of uranium daughters $\left({ }^{234} \mathrm{Th}\right.$ and $\left.{ }^{234 \mathrm{~m}} \mathrm{~Pa}\right)$ in the cylinder. These decay products (heel), which do not vaporize with the UF 6 , tend to collect at the bottom of the cylinders. Exposure rates to personnel working near this cylinder are in the range of 5 to $15 \mathrm{mR} / \mathrm{hr}$.

Conditions similar to those mentioned above may also be encountered when working with tails from the enrichment process.

The product cylinder is moved to another location where the contents are transferred to smaller cylinders for shipment to fuel fabrication plants. The product is also reheated and sampled at this time to verify the degree of enrichment. As mentioned above, some potential exists for release of $U_{6}$ during these operations.

Product cylinders that are ready for shipment may have exposure rates of a few $\mathrm{mR} / \mathrm{hr}$. The greatest external doses are received by workers who handle the various cylinders retained at the enrichment plants. One site measured a maximum dose to an individual of about one rem per year. Typically most workers receive less than half this exposure. 
Maintenance work is performed on equipment after it has been removed from the system. A cascade that needs repair can be valved-off from the system, evacuated, and purged until only trace amounts of $U F_{6}$ remain. Some $U F_{6}$ may remain trapped in parts of the cascade, and there are some deposits of uranium daughters $\left({ }^{234} \mathrm{Th}\right.$ and $\left.234 \mathrm{~m} \mathrm{~Pa}\right)$. Typical dose rates on parts are 1 to $10 \mathrm{mrem} / \mathrm{hr}$ (beta and gamma). Contamination levels may be $1000 \mathrm{cpm}$ alpha and 100 to $500 \mathrm{cpm}$ smearable beta and gamma. Maintenance activities involving manual operations, such as grinding and cutting on contaminated parts, produce a potential for airborne material.

The maintenance area is also where the uranium daughters (heels) are cleaned from cylinders. This process is done using steam jets with the contaminated condensate collected for processing. Processing of radioactive wastes includes chemical separation of uranium and subsequent calcining to $\mathrm{U}_{3} \mathrm{O}_{8}$ powder for future reuse. These activities carry with them the potential for accidental loss of containment and worker exposure but do not represent a large source of routine exposure.

\subsection{NONRADIOLOGICAL HAZARDS}

In the enrichment process area, low levels of fluorides exist at times. Any leakage of $U_{6}$ to the atmosphere results in the formation of uranyl fluoride $\left(\mathrm{UO}_{2} \mathrm{~F}_{2}\right)$ and hydrogen fluoride (HF) gas. Maintenance personnel are most likely to receive exposures during repair of improperly functioning cells containing trapped $\mathrm{UF}_{6}$. The likelihood of exposure is greatly reduced for these workers, however, because this hazard is well known, and a rigid respiratory protection program is followed. An inadvertent leak would be more likely to produce a high but brief exposure to the surrounding workmen. Since the gas is visible in air, the source could be quickly identified and repaired. This rapid identification via observation decreases the occurrence of significant exposures.

Because $U_{6}$ is highly corrosive, much of the piping throughout the enrichment system is of nickel or stainless steel. This presents a concern during welding because nickel and chrome fumes are suspected carcinogens. Nickel exposures are also possible during the manufacture of the diffusion 
barriers, which is a special porous medium used in the enrichment process. A metallic nickel powder is used in barrier production. A recently completed study was designed to ascertain whether mortality from respiratory cancer among barrier workers exposed to airborne metallic nickel differed from that among plant employees with no occupational exposures (Godbold and Tompkins 1979). The results of the study do not support the contention that there is a substantial risk of respiratory malignancies to workers exposed to this nickel material. Other contaminants in the enrichment process include asbestos, sulfuric acid, and nitric acid.

Air monitoring and urinalysis programs are conducted for the detection of contaminants at enrichment facilities. Sampling frequencies for urinalysis vary depending upon exposures. Action levels for 28 urinary contaminants have been established at one facility.

\subsection{RADIOLOGICAL HEALTH PRACTICES}

Discussions of facility monitoring, exposure control, and exposure evaluation practices specific to enrichment facilities are presented below. Facility monitoring, exposure control and evaluation are significant factors in the radiological health program at enrichment facilities.

\subsubsection{Facility Monitoring}

Facility monitoring at enrichment plants varies depending upon plant location. Because the diffusion cascade operates at a vacuum relative to atmospheric pressure, airborne uranium is normally not present. As a result, sampling for airborne particles is not performed routinely. Instead, smoke detectors are used to alarm in the presence of any $\mathrm{UO}_{2} \mathrm{~F}_{2}$ formed following a release of $U_{6}$. Also, because $U_{2} F_{2}$ is highly visible as a white cloud, the release point can be rapidly identified. Decontamination and disassembly areas are sampled routinely for airborne particles. Uranium is present in these areas as a corrosion oxide film of $\mathrm{UO}_{2} \mathrm{~F}_{2}$ and $\mathrm{UF}_{4}$. These areas are also periodically surveyed for surface contamination. Maintenance shops are not routinely sampled for general airborne contamination but are subject to local air sampling during special activities with the potential for airborne uranium. 
Gamma radiation surveillance is not routinely performed at enrichment facilities.

\subsubsection{Exposure Control}

Exposures at enrichment facilities are controlled through the use of engineering design, respiratory protection, and employee training. An example of engineering design is the provision of vacuum hoses at connections to $\mathrm{UF}_{6}$ cylinders to draw away any leakage during connection or disconnection. Respiratory protection is required during specified routine and maintenance activities. Whenever a connection to a $U F_{6}$ system is made or broken (including drawing a UF 6 sample or attaching a UF 6 cylinder to the cascade), a half-face mask is required. One facility has installed an interlock system on the product withdrawal cylinder to prevent movement of the cylinder prior to disconnection of the pigtail. Respiratory protection is also required when cascade equipment is opened for maintenance, and during other maintenance activities such as grinding and cutting contaminated equipment.

\subsubsection{Exposure Evaluation}

Evaluation of exposures is accomplished through a program of lung counting, urinalysis, and external radiation monitoring. The frequency of urinalysis varies depending upon the type of work and its location. Workers with a potential for multiple low-level exposures (e.g., during the connecting and disconnecting of $U_{6}$ cylinders) are scheduled monthly, while all other workers are scheduled quarterly. Chest counts are performed annually for workers exposed to less soluble forms of uranium, e.g., workers in the decontamination facility, compressor disassembly mechanics, and some field maintenance workers. A11 other workers are counted every 2 years. External exposures are monitored through the use of TLD or film badges.

Chest counting, urinalysis, and other monitoring and exposure data are kept for each employee. These records are maintained on a computerized data storage system for ease of retrieval. 


\subsection{REGULATORY PROCEDURE}

Since the Manhattan Project was begun, enrichment facilities have been regulated by federal agencies. Prior to the Energy Reorganization Act of 1974, the Atomic Energy Commission (AEC) regulated the facilities. Since then, the Energy Research and Development Agency (ERDA) (1974 to 1977) and DOE (1977 to present) have regulated these facilities.

When OSHA was established, AEC wished to retain responsibility for the occupational safety and health of employees at its government-owned, contractoroperated facilities under the Atomic Energy Act of 1954. The AEC had previously exercised the authority to require safety and health programs at its contractoroperated facilities under the Atomic Energy Act of 1954. The AEC wished to retain this control of the safety and health program primarily because the OSHA provision for individual state programs could lead to nonuniform application of standards. The Department of Labor accepted AEC's argument that it be allowed to continue enforcing its own occupational safety and health programs at its contractor-operated facilities. The Department of Energy inherited this authority. The authority, however, extends only to those facilities that DOE operates subject to the Atomic Energy Act of 1954.

Today, all enrichment facilities are owned by DOE and operated by a private corporation under contract with DOE. As mentioned above, these facilities are also regulated by DOE. Such facilities are not formally licensed. All contracts to operate DOE facilities contain a health and safety clause which stipulates that the facility will be operated in accordance with DOE Orders.

Because a DOE field office may amend Orders to "fit" a particular facility, the types of personnel protection programs at different facilities may vary even though they are all operated for DOE.

Implementation of health and safety programs at DOE facilities is the responsibility of the program offices. This responsibility is dispatched through the DOE operations offices. All three enrichment plants are administered by DOE's Oak Ridge Operations Office. The responsibility for ensuring that the government contractors provide sufficient health and safety programs at enrichment facilities, therefore, rests with Oak Ridge Operations. There 
are three mechanisms which the operations office may use to ensure proper implementation of health and safety programs: complaint investigations, inspections, and appraisals.

In its role as health and safety administrator, DOE does not operate in a regulatory atmosphere. The safety program, therefore, operates under the concept that DOE identifies the means of meeting the safety and health program objectives. It is then the responsibility of the contractor to provide the expertise and staff that can develop and execute the program. The role of the operations office is one of direction and consent.

DOE's standards for radiation protection are contained in DOE Order 5400 Chapter XI (0524). These standards are based upon the recommendations of the Federal Radiation Council, the Environmental Protection Agency, and the National Council on Radiation Protection and Measurement (NCRP). DOE's standards for uranium are identical to those of the NRC, except for the limits for natural uranium. These limits are based on the "special curie." In practice there is 1ittle difference between DOE's and NRC's radiation protection standards for natural uranium.

DOE's general operational safety standards are contained in DOE Order 5001 Chapter I (0550). DOE facilities are not subject to the Occupational Safety and Health Act of 1970. Standards set forth in 29 CFR Part 1910 are applicable in addition to DOE Order 5001 Chapter I (0550) requirements. Threshold 1 imit values (prescribed by ACGIH 1980) are part of the health protection standards prescribed by DOE. DOE's radiation standards are shown in Table 4.1.

Monitoring for exposures is required for any individual who has the potential to receive a dose in excess of $10 \%$ of the quarterly or annual standard. Monitoring must be conducted for external radiation--primarily by dosimeters-and internal radiation--primarily by bioassay analysis and in-vivo monitoring.

Exposure to radiation in excess of the standards requires that the worker be placed on restriction--that is, reassigned to work that will not increase exposure. Employees are sometimes put on restriction at levels less than the maximum dose equivalent if it is possible they could receive additional 
TABLE 4.1. Radiation Protection Standards for External and Internat Exposures

\begin{tabular}{lcc} 
Type of Exposure & Exposure Period & $\begin{array}{c}\text { Dose Equivalent } \\
\text { (rem) }\end{array}$ \\
\cline { 1 - 1 } $\begin{array}{l}\text { Whole body, head and } \\
\text { truck, gonads, eye lens, } \\
\text { red bone marrow, active }\end{array}$ & year & 5 \\
blood-forming organs & & 3 \\
Unlimited areas of the & year & \\
skin and other organs & quarter & 15 \\
and tissues & & 5 \\
Bone & year & \\
& quarter & 30 \\
Forearms & year & 10 \\
& quarter & 30 \\
Hands and feet & year & 10 \\
& quarter & 75 \\
& & 25
\end{tabular}

exposure that would exceed the standard. Placing workers on restriction for less than the maximum level is left to the discretion of the contractor.

Records of exposure are kept by contractors and reported periodically to DOE.

\subsection{SUMMARY}

The industry has been regulated by federal agencies (including AEC, ERDA, and currently DOE) since its inception in the 1940s. The uranium enrichment industry consists of three separate facilities with a total of approximately 2000 workers with a potential for uranium exposures. The greatest potential for inhalation exposures in enrichment facilities is from inadvertent releases during sampling of uranium hexafluoride $\left(\mathrm{UF}_{6}\right)$ which forms $\mathrm{UO}_{2} \mathrm{~F}_{2}$ and $\mathrm{HF}$ in the

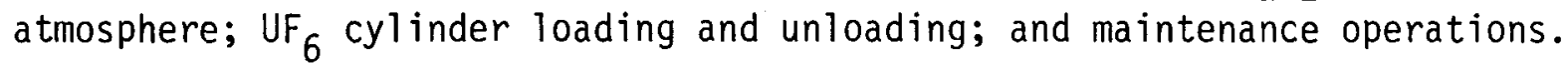
A program of facility monitoring, exposure control and evaluation is designed to reduce potential exposures through inhalation. External exposures are not significant. 


\subsection{FUEL FABRICATION PLANTS}

Fuel fabrication is a physical and chemical process that converts enriched $\mathrm{UF}_{6}$ to uranium dioxide $\left(\mathrm{UO}_{2}\right)$ powder and then mechanically forms the $\mathrm{UO}_{2}$ into pellets, which are loaded into fuel assemblies. The current fuel fabrication industry in the United States consists of seven facilities that perform all or a portion of the fabrication processes necessary to produce finished fuel assemblies. These facilities are located in Pennsylvania, Connecticut, Virginia, North Carolina, South Carolina, Missouri, and Washington State. Table 5.1 is a listing of the fuel fabrication plants. Three facilities have the capability to accept enriched $U_{6}$ as feed and produce finished fuel assemblies. Two other facility carry the process only as far as $\mathrm{UO}_{2}$ powder or pellet production, then two different facilities complete the process by accepting $\mathrm{UO}_{2}$ powder or pellets and producing finished assemblies.

TABLE 5.1. Currently Operating Fuel Fabrication Facilities

\begin{tabular}{|c|c|c|c|}
\hline \multirow{2}{*}{\multicolumn{4}{|c|}{$\frac{\text { Company/Plant Name }}{\text { Babcock and Wilcox Company }}$}} \\
\hline & & & \\
\hline Numec Facility & Apol10, PA & $\mathrm{UF}_{6}$ to $\mathrm{UO}_{2}$ & 1957 \\
\hline B\&W Facility $(a)$ & Lynchburg, VA & $\begin{array}{l}\text { powder } \\
\mathrm{UO}_{2} \text { powder to } \\
\text { final assembly }\end{array}$ & 1975 \\
\hline $\begin{array}{l}\text { Combustion Engineering Inc. } \\
\text { CE Power System Hdqtr. }\end{array}$ & Windsor, CT & $\begin{array}{l}\text { U0 } 2 \text { powder to } \\
\text { fihal assembly }\end{array}$ & 1968 \\
\hline CEI Facility & Hematite, M0 & $\begin{array}{l}\mathrm{UF}_{6} \text { to } \mathrm{UO}^{\mathrm{p}} \text { pow- } \\
\text { der and pellets }\end{array}$ & 1957 \\
\hline $\begin{array}{l}\text { Exxon Company, USA } \\
\text { Nuclear Fuel Fabrication } \\
\text { Facility }\end{array}$ & Richland, WA & $\begin{array}{l}\mathrm{UF}_{6} \text { to final } \\
\text { assembly }\end{array}$ & 1970 \\
\hline $\begin{array}{l}\text { General Electric Company } \\
\text { Wilmington Facility }\end{array}$ & Wilmington, NC & $\begin{array}{l}\mathrm{UF}_{6} \text { to final } \\
\text { assembly }\end{array}$ & 1968 \\
\hline $\begin{array}{l}\text { Westinghouse Electric Corporation } \\
\text { Columbia Fuel Fabrication } \\
\text { Facility }\end{array}$ & Columbia, SC & $\begin{array}{l}U F_{6} \text { to final } \\
\text { assembly }\end{array}$ & 1969 \\
\hline
\end{tabular}

(a) Facilities visited by Registry personnel. 
For the six fuel fabrication facilities visited by Registry personnel, production capacities ranged from 330 to 880 tons of uranium per year (299 to $798 \mathrm{t} / \mathrm{yr})$. The entire industry has approximately 1400 production and maintenance workers.

\subsection{PROCESS DESCRIPTION}

The three basic phases of fuel fabrication are the production of $\mathrm{UO}_{2}$ powder, the production of sintered pellets, and final fuel assembly. In addition, facilities commonly have waste recycle operations to recover uranium from process wastes. Figure 5.1 is a diagram of the three phases.

Fuel fabrication facilities are typically large standard-type industrial buildings with a single noncompartmentalized process area for powder and pellet production. This process area, which includes the pin loading step in the fuel assembly process, comprises the controlled area or area of airborne contamination potential. Beyond the pin loading step, all radioactive material is contained within the fuel pin cladding. The controlled area is physically separated from the remainder of the plant and is maintained at a negative relative pressure.

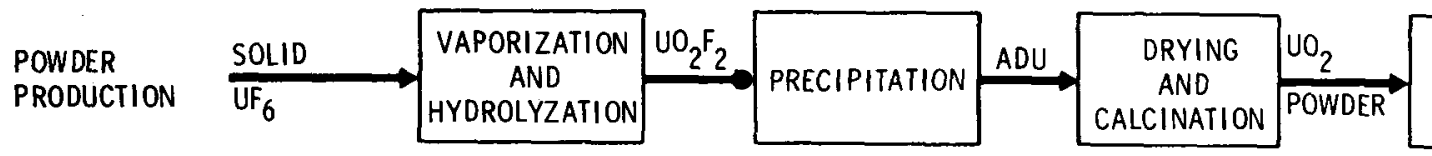

PACKAGINO

PELLET

PRODUCTION
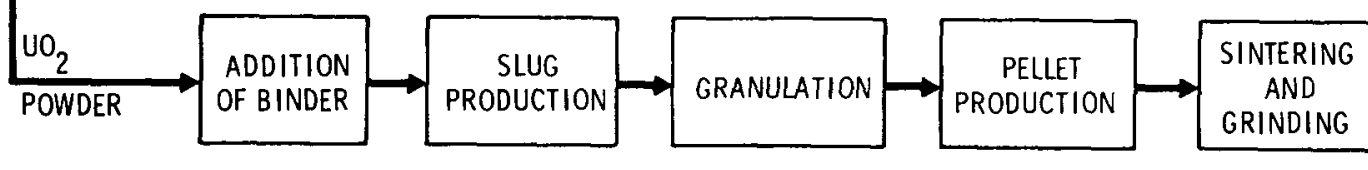

FUEL

ASSEMBLY

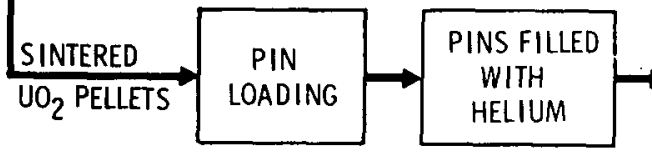

ARRANGEMENT

OF PINS INTO $\longrightarrow$ FINAL FUEL ASSEMBLY

ASSEMBLIES

FIGURE 5.1. Flow Diagram of Fuel Fabrication Process 
The following is a brief review of the three phases of the fuel fabrication process.

\subsubsection{Powder Production}

Solid UF 6 which has been enriched in ${ }^{235} U(2 \%$ to $5 \%)$ is shipped to the fuel fabrication facility in 2.5-ton steel cylinders. Prior to processing, the $U F_{6}$ is vaporized. This is accomplished by placing the cylinders in vaporizers for six hours. This heats the $U_{6}$ to temperatures between $60^{\circ} \mathrm{C}$ and $80^{\circ} \mathrm{C}$. From the vaporizers, the $U_{6}$ is piped to a hydrolyzation column where a reaction with water spray at atmospheric pressure forms uranyl fluoride $\left(\mathrm{UO}_{2} \mathrm{~F}_{2}\right)$ and hydrofluoric acid (HF). If necessary, the uranyl fluoride is pumped into a second column for $\mathrm{pH}$ adjustment before being piped to the precipitation equipment.

The uranyl fluoride is reacted with ammonium hydroxide to form ammonium diuranate precipitate $\left[\left(\mathrm{NH}_{4}\right)_{2} \mathrm{U}_{2} \mathrm{O}_{7}\right]$ and water. This reaction takes place in either a precipitation column or mixing trough. In the trough, mixing is enhanced by hoe-type mixers that rake the mixture back and forth.

The ammonium diuranate slurry is "dewatered" to a paste consistency (50\% solid) before being sent to the dryers. "Dewatering" equipment currently in use includes centrifuges, a continuous belt apparatus that uses a partial vacuum to pull excess water out of the paste, and settling tanks. The excess water is fed through filters and treated before being released. The dryers include gas-fired and infrared lamp dryers, both of which produce ammonium diuranate with $2 \%$ to $5 \%$ moisture content.

Calcination of the ammonium diuranate to uranium dioxide $\left(\mathrm{UO}_{2}\right)$ takes place in a gas-fired rotary calciner under a hydrogen atmosphere or a cracked ammonia atmosphere. Calcination is sometimes a two-stage process with intermediate conversion to uranium oxide $\left(\mathrm{U}_{3} \mathrm{O}_{8}\right)$ in a rotary calciner under an air atmosphere.

After calcination, the $\mathrm{UO}_{2}$ is conveyed to a hammer mill for pulverization followed by load-out into plastic containers at some facilities or by conveyor transport directly to the pellet area at others. Some facilities include a homogenation operation that empties a batch of containers, then refills them a 
layer at a time from each of the other containers. At facilities that terminate the process at this point, the containers are placed into transportation overpacks for shipment to other facilities. Before shipment, a representative sample of the $\mathrm{UO}_{2}$ is pressed and sintered to verify the acceptability of the $\mathrm{UO}_{2}$ shipment. The next stage in the fuel fabrication process is pellet production.

\subsubsection{Pellet Production}

Containers of $\mathrm{UO}_{2}$, whether received from the powder production area or a separate facility, are opened and the contents sampled. The containers are then resealed and taken to the pelletizing area. Here $\mathrm{UO}_{2}$ powder containers are emptied into a large blending hopper or fluidized bed blender along with binder material and are blended. Some facilities press the $\mathrm{UO}_{2}$ before adding binder. In these cases, $\mathrm{UO}_{2}$ containers are emptied in a hood and the $\mathrm{UO}_{2}$ is fed through a roll press. The containers are then refilled and the binder is added. Blending is accomplished by rolling the containers, which are then emptied into a hopper.

From the hopper, the $\mathrm{UO}_{2} /$ binder is fed into a slug press that produces nickel-sized $\mathrm{UO}_{2}$ slugs. The slugs are lifted by an elevator to a granulatory that produces granulated $\mathrm{UO}_{2}$ feed to the pellet press.

The pellet press takes the $\mathrm{UO}_{2}$ feed and produces green (unsintered) pellets. The press is contained within a ventilated enclosure open only at the pellet exit point. The pellets are loaded by hand onto trays and taken to the sintering furnace. The trays of pellets move through the furnace automatically and are sintered in a hydrogen atmosphere.

Sintered pellets are gound, wet or dry, to the proper dimensions. When dry grinding is used, the equipment is contained within a ventilated plexiglass enclosure. Wet grinding is done in an unenclosed area. The ground pellets are randomly tested chemically and for size. All pellets are visually inspected and packaged for storage until needed in the fuel assembly area. 


\subsubsection{Fuel Assembly}

The inspected $\mathrm{UO}_{2}$ pellets are taken to the pin loading area where they are mechanically fed into prepared fuel pins. Once filled, the pin is sealed with an end cap, wiped clean, checked for contamination, and removed from the controlled area. Beyond this point, the pellets are contained within sealed fuel pins and the process areas are considered noncontrol areas (10w airborne contamination potential).

After the end caps are welded, the pins are evacuated through a laserproduced hole in the end cap and filled with helium gas. The hole is welded shut and the pins are processed through a series of cleaning and testing $Q A$ steps. Acceptable pins are assembled into final fuel assemblies that are inspected and placed into storage to await shipment.

Some of the fabrication plants include equipment and facilities for the manufacture of other fuel assembly components. These components include gadolinium poison rods and boron carbide control rods. The production of these components involves working with gadolinium and boron carbide powders, and, in the case of gadolinium, the production of gadolinium pellets.

\subsection{RADIOLOGICAL EXPOSURES}

This section provides a discussion of radiological occupational exposures in the three basic phases of fuel fabrication. Exposures may occur during routine operations, periodic maintainance, or as a result of accidental loss of containment.

A significant portion of the fuel fabrication process consists of powder handling operations involving insoluble uranium compounds. As a result, inhalation is a major concern. The open layout of the controlled area makes it possible to be exposed to a uranium compound while not actually working at the location of a release; therefore, exposures to a mixture of compounds from different process areas could occur. Intensive quality control inspections required in the fuel assembly area result in the most significant external exposures. 
This section reviews radiological exposures in the three phases of the fuel fabrication process.

\subsubsection{Powder Production}

Workers could potentially be exposed to $\mathrm{UO}_{2} \mathrm{~F}_{2}$ which is formed when $\mathrm{UF}_{6}$ comes into contact with moisture in the air. Any $U_{6}$ left in the line to a cylinder when the connection is broken will escape and form $\mathrm{UO}_{2} \mathrm{~F}_{2}$. Chronic exposure to $\mathrm{UF}_{6}$ is unlikely as very small amounts of $\mathrm{UO}_{2} \mathrm{~F}_{2}$ form a readily apparent white mist in the air. The hydrolization step takes place in enclosed equipment preventing release of process material during routine operation.

There is a higher probability of releasing ADU into the working environment in those facilities that use a hooded mixing trough as opposed to those that use a closed precipitation column. Although the concentrations of particulate radioactive material in the air are not a significant hazard, the solution can come into contact with the skin owing to splashing during the mixing process. Absorption through the skin could be a significant pathway of exposure to radioactive materials. The area in which the ADU is handled contributed the highest worker exposures at some plants.

As the ADU passes through the dryers, moisture content is further reduced to $3 \%$ to $5 \%$. Although the resulting ADU is a dry powder, the drying equipment is enclosed preventing significant release. The interior of some drying equipment is readily accessible through normally closed inspection ports representing a potential source of exposure.

Calcination to $\mathrm{UO}_{2}$ and pulverization both take place in enclosed equipment that normally does not allow material to be released. The enclosed conveying equipment between the calciner and ball mill as well as the ball mill enclosure are subjected to equipment vibration and motion. This has resulted in seal leakage and locally increased air concentrations. At some plants, the background air concentration in this area was about $40 \%$ of the maximum permissible concentration (10 CFR Appendix B).

Overa11, general background concentrations of airborne uranium in the powder production area are on the order of 25\% of MPC (10 CFR 20, Appendix B). Air concentrations for specific locations may exceed the background levels. 


\subsubsection{Pellet Production}

The first step in the pellet production process is powder sampling. In the case of $\mathrm{UO}_{2}$ arriving in containers, the container is placed in or near a ventilated hood, the lid is removed, and the sample is taken. Average air concentrations in this area have been in the range $25 \%$ of the MPC.

Binder is added to the $\mathrm{UO}_{2}$ containers directly or is mixed with $\mathrm{UO}_{2}$ using blending equipment. At facilities using the first method, the container is manually opened inside an open-faced hood and a premeasured amount of binder is added. The closed container is then rolled to blend in the binder. Facilities using blending equipment either feed the $\mathrm{UO}_{2}$ directly to the equipment from the powder area or, if containers are used, manually empty the containers inside a glove box and into the equipment.

Prepressing equipment consists of either a roll press or slug press followed by a granulator. The slug press and granulator, including the connecting slug elevator, are enclosed and ventilated with the $\mathrm{UO}_{2}$ fed to the press and removed from the granulator automatically. The roll press is also fully enclosed and ventilated. The $\mathrm{UO}_{2}$ is manually fed to and removed from the press in ventilated hoods. Recycled $\mathrm{U}_{3} \mathrm{O}_{8}$ powder is also fed back into the process at this point.

The pellet presses are contained in ventilated plexiglas enclosures that are open at the die for pellet removal. The worker is positioned at the opening to remove pellets as they are produced and place them on trays for sintering. Average airborne concentrations in this area are commonly in the range of $25 \%$ to $50 \%$ of the allowable limits.

After sintering, the pellets are ground to the proper dimensions using either wet or dry grinding equipment. Wet grinding maintains a constant flow of water on the pellet, eliminating the need for an enclosure and ventilation al though some splattering does occur. The dry grinding equipment is completley enclosed and ventilated during operation except for a small inlet and outlet port for the pellets. Airborne concentrations in this area are normally not greater than the general area background concentration range of $20 \%$ to $40 \%$ of MPC. 


\subsubsection{Fuel Assembly}

In the fuel fabrication process only the pin loading step involves handling uncontained uranium. Airborne concentrations in the pin loading area range from $5 \%$ to $20 \%$ of the 10 CFR 20 allowable limit. A potential physical hazard in this area is the use of lasers. A laser is used to drill the hole in end caps, but since the unit is entirely enclosed and in a fixed position, no hazard is apparent.

The remainder of the fuel assembly process involves handling sealed fuel pins that prevent airborne release of the $\mathrm{UO}_{2}$ under normal conditions. The extensive inspection required for pins and particularly the finished assemblies results in the highest external gamma doses to fuel fabrication workers. Average annual dose is on the order of 500 mrem with maximum individual annual doses as high as 2 rem.

\subsection{NONRADIOLOIGCAL HAZARDS}

The most prevalent nonradiological exposure throughout fuel fabrication facilities is to ammonia used in the powder production phase. In one facility visited, a strong odor of ammonia gas was noticeable in the autoclave area, but the gas was reportedly coming from the ammonia recovery plant. There, a wastereceiving tank is vented to the atmosphere in a manner that occasionally causes ammonia to return to the plant. Concentrations as high as $15 \mathrm{ppm}$ are not uncommon, and a scrubber to prevent gas recirculation is to be added to the system. The TLV-TWA for ammonia in air is $25 \mathrm{ppm}$ (ACGIH 1980). In another facility, an ammonium hydroxide tank in the ADU area had a plugged line, and the solution had backed up and spilled onto the floor. This was considered to produce an airborne ammonia level of 75 to $100 \mathrm{ppm}$ (the "normal" level is reportedly 5 to $10 \mathrm{ppm}$ ). The floor looked as if many spills or leaks had occurred. In order to determine ammonia levels in this area, breathing zone and area samples are taken periodically.

After the $\mathrm{ADU}$ and $\mathrm{U}_{3} \mathrm{O}_{8}$ are calcined in the powder production phase, additional potential for fluoride exposure exists. In all facilities visited, 
occupational exposures to fluorides are extremely low, and the concern with respect to fluorides is environmental (from stack emissions). This conclusion was based on past monitoring activities.

In the fuel assembly phase, completed fuel assemblies are cleaned with acetone, which is obtained from a dispenser and manually wiped onto the assemblies. Although no quantitative data were available, exposure to acetone may present a problem.

Nitric acid is used to dissolve uranium in waste recovery operations. Nitric acid is also used for cleaning purposes at the ammoniator. These operations involve potential exposures to peak concentrations of $\mathrm{NO}_{2}-\mathrm{NO}_{x}$, especially during the opening of digester doors. Sampling has been done for oxides of nitrogen at the facilities. Perchloroethylene and tributyl phosphate are used in conjunction with nitric acid for waste cleanup in at least one facility. Exposures to these vapors reportedly are not excessive.

Another area of potential airborne ammonia is in the radioactive waste area where ammonium hydroxide is used. Normal gas levels here are 30 to $50 \mathrm{ppm}$, and the odor of ammonia was easily noticeable during our visit. For this and all areas where spills or leaks may occur, cleanup is usually accomplished by a simple mopping procedure. This suggests that maintenance personnel may be exposed to the highest ammonia concentrations.

Other chemicals of interest used in fabrication include trichloroethylene, trichloroethane, hydrofluoric acid, sodium hydroxide, and hydrochloric acid. A variety of the potential hazards common to the rest of the uranium industry are also found in fuel fabrication, for instance welding and metal-cleaning procedures.

\subsection{RADIOLOGICAL HEALTH PRACTICES}

Radiological health practices at fuel fabrication facilities include facility monitoring and exposure control and evaluation, which are described below.

\subsubsection{Facility Monitoring}

Breathing air in the working environment at fuel fabrication facilities is monitored for airborne particulate radioactivity. Two types of air samples are 
taken, general area or background samples and breathing zone samples. Processes that are made up of several specific work stations (e.g., pellet production process) lend themselves to breathing zone samples. Processes that have few fixed work locations (e.g., powder production process) lead to a greater dependence on general area samples.

Fuel fabrication facilities have between 100 and 160 fixed air sampler locations. The samplers are mostly continuous air monitoring systems where the air is constantly sampled and the samples are periodically collected and analyzed. Some fabrication facilities employ air monitoring sytems to provide real-time indications of air concentrations in selected areas that have higher air concentrations. These systems are often set to alarm in the event of high radiation levels. Some facilities use high volume air samplers during special activites such as maintenance. Samples from continuous air monitoring systems are collected at the end of every shift and counted for total activity or for gross alpha. This is typical for monitors in the controlled area. In the uncontrolled area, the air is not continuously monitored. Instead, periodic grab samples are obtained.

Lapel samplers are used at all facilities for routine spot checks. These devices are also used in instances of suspected high airborne contamination levels.

External radiation levels are monitored by routine gamma surveys or dosimeters (TLDs or $f i 1 \mathrm{~m}$ ) located through the process areas.

Surface contamination surveys are conducted routinely by all fuel fabrication facilities. These surveys can sometimes be conducted both visually and by taking smear samples. The schedules for taking smears varies depending on location in the plant.

\subsubsection{Exposure Control}

Personnel exposures are controlled through basic engineering design, the use of respiratory protection, protective clothing, and employee training programs. 
Process and equipment containment, dust collection and indoor area ventilation are the primary engineering design features that prevent airborne radioative material from reaching unacceptable levels. The vaporization of UF 6 takes place in an area which is somewhat isolated (often with a plastic hood) from the main process area and which has a separate ventilation system. This protects the workers from excessive exposure to UF 6 which can occur when the connections to the $\mathrm{UF}_{6}$ cylinders are broken. Areas of the facility are cleaned frequently to remove any dust and powder that may accumulate. At some plants, the pellet press area is mopped at least three times a day to remove any source of contamination. The air in the facilities can be cleaned by circulating it through high efficiency particulate air (HEPA) filters and charcoal filters.

Where necessary, inhalation exposures are controlled through the use of respiratory protection. Respirators are required for certain operations in areas of high air concentrations. Some facilities require air masks in the vaporization area when the UF 6 cylinder connections are broken and in the pellet area when the connection to the granulator is made or broken. 0ther plants do not require respirators during normal operation, although they are used when tearing down or servicing a piece of equipment. Most facilities have onsite mask fitting and testing equipment and can fit their employees with more than one type of respirator.

Working clothing or overalls are used by all facilities for personnel contamination control with certain processes requiring additional protection. For example, gloves may be required at the roll press because of the close proximity of the worker to open trays of $\mathrm{UO}_{2}$ and $\mathrm{U}_{3} \mathrm{O}_{8}$. The use of gloves reduces beta exposures to workers' hands. Eye protection is required by at least one facility in an area where uranium dioxide is dumped into poly-lined fiber buckets.

All uranium production facilities are required to provide a radiological protection training program for all employees who work with or around radioactive materials. Some plants have a periodic retraining schedule for employees. Operating procedures are also often posted in the work areas. 


\subsubsection{Exposure Evaluations}

Personnel dosimeters (TLDs or film badges) are used to evaluate external gamma-beta exposure. Most fuel fabrication facilities issue TLDs to all uranium workers at their facility. However, one facility issues TLDs to a few typical workers as a check on exposures being received. The TLD badges are collected monthly or quarterly depending on the facility. One plant has a monthly exchange schedule for the dosimeters that are used to read neutron levels and a quarterly exchange schedule for beta-gamma dosimeters. The TLDs are often sent offsite to be analyzed.

Inhalation exposures to workers may be estimated from the results of air monitoring and a record of the time spent by employees in the monitored area. At some plants, automatic exposure estimates are obtained from computerized monitoring of card entry and exit into areas multiplied by the eight-hour profile of the air concentration that is on the computer. Extremity doses can be calculated based on the mass of the material handled and the amount of time spent handling this material. One plant divides workers into two separate categories depending on the frequency of exposure. Daily workers in areas of airborne contamination have their exposures calculated each day, while employees who work in these areas only occasionally have exposures calculated each week. Comparisons are made between the exposures calculated from air sample readings and those determined through urinalysis. The air sample doses have been found to be conservative and higher than those determined by urinalysis.

Several methods are used for direct and indirect bioassay at fuel fabrication plants. The direct bioassay methods include whole body counting and chest counting. Indirect bioassay methods include measurement of radioactivity levels in excreta (urine and feces) and nasal smears.

Whole-body counting is done by either in-house facilities or by vendorsupplied services. Counting schedules are usually based on either work location or exposure potential. One facility routinely schedules two whole body counts per year for workers exposed to uranium. 
Chest-counting schedules are based on job location or are administered on a fixed schedule, as in one plant that required one per quarter. Some of the larger facilities have onsite counting equipment; other facilities use university or vendor-supplied counters.

Urine samples are collected in the change room and are analyzed in-house or are sent to commercial laboratories for analysis. Fluorometry is the most frequently used method of urinalysis.

Urine sample collection schedules are based on the work location or the employee's MPC hours. In the case of MPC hours, the urinalysis schedule may change from one period to the next if the air concentrations increase or decrease for any reason. These facilities constantly reassess the need to conduct bioassays based on the MPC levels. At one facility, the frequency of urine sample collection varies from daily (for vaporization workers with potential for inhalation of soluble uranium compounds [e.g., $\left.\mathrm{UO}_{2} \mathrm{~F}_{2}\right]$ ) to annually (for workers in areas with the potential for inhalation of insoluble uranium compounds $\left[\mathrm{e} . \mathrm{g} \cdot, \mathrm{UO}_{2}\right]$ ).

Other methods of exposure evaluation include fecal sampling and nasal sampling. Most sites use fecal samples for analysis only after an acute exposure. Home fecal sample kits are provided for the workers. Nasal smear surveys are required regularly for workers at certain jobs. Other workers at most facilities take nasal smears on a random basis. At a single facility, nasal smears are taken daily at the end of the shift.

In the event of a known inhalation of uranium, an integrated system of exposure evaluation is begun. Fecal and urine sampling is begun immediately and continued for at least three days. In addition, some facilities require morning and evening lung counts and a whole-body count. Fixed air sample results along with an estimate of worker exposure time are also used to estimate the internal dose.

The data from the exposure evaluations are recorded and maintained at the facilities. Most facilities store this information on computers, although some still use hard copies. 
Information commonly recorded includes

- Employee information

- age, sex, weight, height, chest thickness

- job function

- respirator use

- assigned and potential exposures

- training history

- respirators fitted

- Lung count - $\mu$ gm ${ }^{235} \mathrm{U}$

- Urinalysis - $\mu \mathrm{gm} / \ell$ or $\mathrm{dpm} / \ell$

- Fecal count

- External dose

- TLD badges

- finger rings

- Internal exposure information (variable reporting)

- MPC hours, or

- General air concentration, or

- rem based on air concentration

- Miscellaneous

- Nasal smears

- Respirator use

- Lapel sampler

- Body smears

\subsection{REGULATORY PROCEDURE}

Historically, AEC and (since 1974) NRC have been responsible for licensing and regulating commercial uranium fuel fabrication facilities. Fuel fabrication plants are licensed by NRC to process compounds that contain special nuclear materials. The Code of Federal Regulations, Title 10, Part 70 establishes procedures and criteria for licensees to "receive title to, own, acquire, deliver, receive, possess, use, and initially transfer special nuclear material." Special nuclear material is defined as: "plutonium, uranium 233, 
uranium enriched in the isotope 233 or in the isotope 235 , and any other material which the Commission ... determines to be special nuclear material, "which includes any material artifically enriched with those nuclides.

Part 70 continues by specifying license types and conditions of licensing. Some of those conditions bring licensees under other related parts of 10 CFR, i.e., Part 71, "Packaging of Radioactive Material for Transport and Transportation of Radioactive Material Under Certain Conditions," and Part 73, "Physical Protection of Plants and Materials." A monitoring system for a criticality accident is also specified under Section 70.24. Other items in Part 70 refer to material accountability, transfer and ownership, inspection, reporting criteria, and enforcement terms.

In addition to 10 CFR 70, fuel fabrication facilties must comply with 10 CFR 20 and 10 CFR 40 as do conversion facilities. A discussion of these regulations can be found in Section 3.5 .

Regulatory Guides that are pertinent to evaluating occupational exposures in fuel fabrication facilities include numbers 8.11, Application of Bioassay for Uranium (AEC 1974); 8.15, Acceptable Programs for Respiratory Protection (NRC 1976a); 8.24, Health Physics Surveys During Enriched Uranium-235 Processing and Fuel Fabrication (NRC 1978b); and 3.39, Standard Format and Content of License Applications for Plutonium Processing and Fuel Fabriction Plants (NRC 1976b).

\subsection{SUMMARY}

The commercial uranium fuel fabrication industry consists of seven facilities with approximately 1400 production and maintenance workers. Historically, the industry has been regulated by federal agencies (originally by the $A E C$ and currently the NRC). The primary inhalation hazard at fuel fabrication facilities is exposure to $\mathrm{UO}_{2}$ during packaging and unpackaging, powder handling, pellet production, and maintenance. Facilities are monitored for radiological hazards and pesonnel exposures are controlled through design engineering and use of protetive clothing and respiratory devices. The most prevalent nonradiological exposure is to ammonia. 


\subsection{REFERENCES}

Chester, R. 0., K. A. Kirkscey and M. L. Randolph. 1979. Survey of Knowledge of Hazards of Chemicals Potentially Associated with the Advanced Isotope Separation Processes. ORNL/TM-6812. Oak Ridge National Laboratory, Oak Ridge, Tennessee.

Allied Chemical Corporation. 1975. Supplemental Report in Support of Application for Renewal of Source Materails License SUB-526. January 1975. Docket No. 40-3392. Metropolis, IlTinois.

American Conference of Governmental Industrial Hygienists, Inc. 1980. Documentation of Threshold Limit Values. 4th ed. Cincinnati, Ohio.

American National Standards Institute. 1966. Practice for Occupational Radiation Exposure Records System. ANSI N13. 6 .

American National Standards Institute. 1980. Practices for Respiratory Protection. ANSI 788.2

Code of Federal Regulations. Title 10, Part 20, "Standards for Protection Against Radiation." 1980.

Code of Federal Regulations. Title 10, Part 40, "Licensing of Source Material." 1980.

Code of Federal Regulations. Title 10, Part 70, "Special Nuclear Material." 1980 .

Code of Federal Regulations. Title 29, Part 1910.134, "Occupational Safety and Health Administration Regulations.

Cool, W. S. 1978. Occupational Radiation Exposure at NRC-Licensed Facilities, 1975. NUREG-0419, U.S. Nuclear Regulatory Commission, Washington, D.C.

Godbold, J. H., Jr., and E. A. Tompkins. 1979., "A Long-Term Mortality Study of Workers Occupationally Exposed to Metallic Nickel at the Oak Ridge Gaseous Diffusion Plant." J. Occ. Med. 21(12):799-806.

Harley, J. E. (ed). 1972. HASL Procedure Manual. HASL-300, Health and Safety Laboratory.

International Commission on Radiological Protection. 1972. The Metabolism of Compounds of Plutonium and Other Actinides. Publication 19. Pergamon Press, Oxford.

International Commission on Radiological Protection. 1977. Recommendations of the International Commission on Radiological Protection. Publication 26. Pergamon Press, 0xford. 
International Commission on Radiological Protection. 1979. Limits for Intake of Radionuclides by Workers. Publication 30. Pergamon Press, Oxford.

International Commission on Radiological Protection. 1966. "Deposition and Retention Models for Internal Dosimetry of the Human Respiratory Tract - Task Group on Lung Dynamics." Health Physics, 12:173-207.

Kalkwarf, D. R. 1979. Solubility Classification of Airborne Products from Uranium Ores and Tailings Piles. PNL-2870, NUREG/CR-0530, Pacific Northwest Laboratory, Richland, Washington

Stoetze1, G. A., D. R. Fisher, W. D. McCormack, G. R. Hoenes, S. Marks, R. H. Moore, D. G. Quilici, B. D. Breitenstein. 1981. Occupational Exposures to Uranium: Processes, Hazards and Regulations - A Field Study of the Commercial Fuel Cycle. PNL-3341, URUS-01. Hanford Environmental Health Foundation and Pacific Northwest Laboratory, Richland, Washington.

U.S. Atomic Energy Commission. 1974a. Applications of Bioassay for Uranium. WASH-1251.

U.S. Atomic Energy Commission. 1974b. Applications of Bioassay for Uranium. Regulatory Guide 8.11, Washington, D.C.

U.S. Nuclear Regulatory Commission. 1976. Manual of Respiratory Protection Against Airborne Radioactive Materials. NUREG-0041.

U.S. Nuclear Regulatory Commission. 1976. Acceptable Programs for Respiratory Programs. Regulatory Guide 8.15.

U.S. Nuclear Regulatory Commission. 1976b. Standard Format and Content of License Applications for Plutonium Processing and Fuel Fabrication Plants. Regulatory Guide 3.39, Washington, D.C.

U.S. Nuclear Regulatory Commission. 1977. Guide for the Preparation of Applications for Licenses to Process Source Materia?. Regulatory Guide 10.4 (Rev. 1).

U.S. Nuclear Regulatory Commission. 1978. Bioassay at Uranium Mills. Regulatory Guide 8.22. Washington, D.C.

U.S. Nuclear Regulatory Commission. 1978. Safety Evaluation Report by Division of Fuel Cycle and Material Safety Related to the Source Material Licensee Renewal of the Kerr-McGee Nuclear Corporation Uranium Hexafluoride Facility, Sequoyah County, Oklahoma. Docket No. 40-8027, License No. SUB-1010.

U.S. Nuclear Regulatory Commission. 1978b. Health Physics Surveys During Enriched Uranium-235 Processing and Fuel Fabrication. Regulatory Guide 8.24, Washington, D.C. 